Article

\title{
Erythromycin Abatement from Water by Electro-Fenton and Peroxyelectrocoagulation Treatments
}

\author{
Anna Serra-Clusellas 1,* , Luca Sbardella ${ }^{1}$, Pol Herrero ${ }^{2}$, Antoni Delpino-Rius ${ }^{2}$, Marc Riu ${ }^{2}$, \\ María de Lourdes Correa ${ }^{1}$, Anna Casadellà ${ }^{1}$, Núria Canela ${ }^{2}$ and Xavier Martínez-Lladó ${ }^{1}$ \\ 1 Eurecat, Centre Tecnològic de Catalunya, Water, Air and Soil Unit, Plaça de la Ciència 2, 08242 Manresa, \\ Spain; luca.sbardella@eurecat.org (L.S.); lulecorrea10@hotmail.com (M.d.L.C.); anna.casadella@irta.cat (A.C.); \\ xavier.martinez@eurecat.org (X.M.-L.) \\ 2 Eurecat, Centre Tecnològic de Catalunya, Centre for Omic Sciences (Joint Unit Eurecat-Universitat Rovira i \\ Virgili), Unique Scientific and Technical Infrastructure (ICTS), 43204 Reus, Spain; \\ pol.herrero@agilent.com (P.H.); antoni.delpino@eurecat.org (A.D.-R.); marc.riu@eurecat.org (M.R.); \\ nuria.canela@eurecat.org (N.C.) \\ * Correspondence: anna.serra@eurecat.org
}

check for updates

Citation: Serra-Clusellas, A.; Sbardella, L.; Herrero, P.

Delpino-Rius, A.; Riu, M.; de Lourdes

Correa, M.; Casadellà, A.; Canela, N.;

Martínez-Lladó, X. Erythromycin

Abatement from Water by

Electro-Fenton and

Peroxyelectrocoagulation Treatments.

Water 2021, 13, 1129. https://

doi.org/10.3390/w13081129

Academic Editor: Christos S. Akratos

Received: 30 March 2021

Accepted: 16 April 2021

Published: 20 April 2021

Publisher's Note: MDPI stays neutral with regard to jurisdictional claims in published maps and institutional affiliations.

Copyright: (c) 2021 by the authors. Licensee MDPI, Basel, Switzerland. This article is an open access article distributed under the terms and conditions of the Creative Commons Attribution (CC BY) license (https:// creativecommons.org/licenses/by/ $4.0 /)$

\begin{abstract}
Electro-Fenton (EF) and peroxyelectrocoagulation (PEC) processes were investigated to mineralize $10 \mathrm{mg} \mathrm{L}^{-1}$ erythromycin from ultrapure water, evaluating the influence of the anode material (BDD and Fe), current density (janode $)\left(5 \mathrm{~mA} \mathrm{~cm}^{-2}\right.$ and $\left.10 \mathrm{~mA} \mathrm{~cm}^{-2}\right)$, oxygen flowrate injected to the cathode $\left(0.8 \mathrm{~L} \mathrm{~min}^{-1} \mathrm{O}_{2}\right.$ and $\left.2.0 \mathrm{~L} \mathrm{~min}^{-1} \mathrm{O}_{2}\right)$ and $\mathrm{pH}(2.8,5.0$ and 7.0) on the process efficiency and the electricity costs. $70 \%$ mineralization was reached after applying $0.32 \mathrm{~A} \mathrm{~h} \mathrm{~L}^{-1}$ under the best operational conditions: PEC treatment at $5 \mathrm{~mA} \mathrm{~cm}^{-2}, 2.0 \mathrm{~L} \mathrm{~min}^{-1} \mathrm{O}_{2}$ and pH 2.8 . The electricity consumption of the electrochemical cell under these conditions was approximately $0.3 \mathrm{kWh} \mathrm{m}^{-3}$. Early-stage intermediates produced from erythromycin degradation were identified and quantified throughout the treatment and a potential erythromycin degradation pathway was proposed. The most appropriate operational conditions tested with synthetic solutions were applied to treat a real effluent from the tertiary treatment of an urban wastewater treatment plant. All emerging compounds listed in the EU Decision 2018/840 (Watch List 2018) were determined before and after the PEC treatment. All listed pollutants were degraded below their quantification limit, except estrone and 17- $\alpha$-ethinylestradiol which were $99 \%$ removed from water. Electricity consumption of the electrochemical cell was $0.4 \mathrm{kWh} \mathrm{m}^{-3}$. Whilst awaiting future results that demonstrate the innocuity of the generated byproducts, the results of this investigation (high removal yields for emerging pollutants together with the low electricity consumption of the cell) indicate the promising high potential of PEC treatment as a water treatment/remediation/regeneration technology.
\end{abstract}

Keywords: erythromycin; peroxyelectrocoagulation; electro-Fenton; Watch List 2018; emerging contaminants; antibiotics

\section{Introduction}

Over the last two decades there has been increasing concern regarding emerging contaminants due to the possible threats they pose to both the human population and the aquatic environment [1]. Wastewater reuse practices, together with more advanced analytical methods to detect substances at levels ranging from ng L ${ }^{-1}$ to $\mu \mathrm{g} \mathrm{L}^{-1}$ [2], have resulted in more advanced and stringent regulations aiming at tackling this environmental problem [3]. At the European Union (EU) level, the first watch list of substances for tracking was published in 2015 [4] establishing 10 substances or groups of substances to be monitored. This watch list aimed to gather data for the future prioritisation of emerging compound regulation in the field of water policy. It was updated in 2018 by the EU Decision 2018/840 [5] (called in this paper, Watch List 2018) and just the last year (EU Decision 2020/1161) it was again modified since "according to Article 8b(2) of Directive 
2008/105/EC, the duration of a continuous watch list monitoring period for any individual substance shall not exceed four years" [6].

Three macrolide antibiotics (erythromycin, clarithromycin, azithromycin) were included in the EU Decision 2018/840 [5] although their monitoring ceased in 2019 [6]. Antibiotics are a class of pharmaceutical active compounds with high usage and consumption worldwide both for humans and animals [7]. They can enter to the environment via several pathways and can, therefore, contaminate different environmental compartments [8]. Their presence has been detected in surface water, groundwater and drinking water [9]. This fact has further increased concern due to their negative effect, including the spread of antibiotic resistance [10].

Among the macrolide antibiotics listed in the Watch List 2018, erythromycin was detected in diverse water matrices such as surface water $\left(85,200\right.$ and $7100 \mathrm{ng} \mathrm{L}^{-1}$ [11]), hospital effluents (127-575 $\mathrm{ng} \mathrm{L}^{-1}$ [12], maximum of $140 \mathrm{ng} \mathrm{L}^{-1}$ [13], 1000-27,000 $\mathrm{ng} \mathrm{L}^{-1}$ [14]), livestock wastewater (139 $\mathrm{ng} \mathrm{L}^{-1}$ [12]), and urban wastewater (179-185 [15]), among others.

The removal of this pollutant from water by various technologies has been studied. More than $88 \%$ and $93 \%$ erythromycin removals from a hospital effluent were obtained by powdered activated carbon and ozone, respectively, at $\mathrm{pH}$ 8.5-8.8 [13]. However, less than $35 \%$ erythromycin degradation was achieved by applying UV-C doses equal to or lower than $7200 \mathrm{~J} \mathrm{~m}^{-2}$ [13], indicating that it is not a photoactive compound at $254 \mathrm{~nm}$. Its total degradation was achieved both by the EreB esterase enzymatic treatment [16] and solar-driven heterogeneous photocatalysis with immobilised $\mathrm{TiO}_{2}$ [15]. However, its degradation percentage diminished by $45 \%$ or $22 \%$ when solar light was simulated during immobilised [16] or suspended [17] $\mathrm{TiO}_{2}$ photocatalysis, respectively. The solar photo-Fenton process also resulted in $100 \%$ erythromycin removal [17].

The results of previous investigations demonstrate that advanced oxidation processes (AOPs) are highly efficient treatments to reach gradual oxidation of erythromycin [15-17] as well as other emerging contaminants [18-21], through the generation of highly reactive oxygen species (ROS) (mostly hydroxyl radical ${ }^{\bullet} \mathrm{OH}$ ) with high oxidation potentials (e.g., $\mathrm{E}^{0} \mathrm{NHE}=2.80 \mathrm{~V}$ in the case of ${ }^{\bullet} \mathrm{OH}$ ) and low selectivity. Among the mechanisms to generate hydroxyl radical, the Fenton process [22] (caused by the decomposition of $\mathrm{H}_{2} \mathrm{O}_{2}$ mediated by catalytic quantities of $\mathrm{Fe}(\mathrm{II})$ under acidic and dark conditions (Equation (1)) has been widely investigated for wastewater treatment $[23,24]$ :

$$
\mathrm{H}_{2} \mathrm{O}_{2(\mathrm{aq})}+\mathrm{Fe}^{2+}{ }_{(\mathrm{aq})} \rightarrow \mathrm{Fe}^{3+}{ }_{(\mathrm{aq})}+\mathrm{OH}^{-}{ }_{(\mathrm{aq})}+{ }^{\bullet} \mathrm{OH}_{(\mathrm{aq})} k=41.7-79 \mathrm{M}^{-1} \mathrm{~s}^{-1}
$$

However, the major drawback of this process is that the regeneration of $\mathrm{Fe}(\mathrm{II})$ takes place by Fenton-like reaction (Equation (2)), which presents a reaction rate much lower than the Fenton reaction:

$$
\mathrm{Fe}^{3+}{ }_{(\mathrm{aq})}+\mathrm{H}_{2} \mathrm{O}_{2(\mathrm{aq})} \rightarrow \mathrm{Fe}^{2+}{ }_{(\mathrm{aq})}+\mathrm{HO}_{2}{ }_{(\mathrm{aq})} k=9.1 \times 10^{-7} \mathrm{M}^{-1} \mathrm{~s}^{-1}
$$

It is for this reason that solar light is usually applied during the Fenton process so as to accelerate the $\mathrm{Fe}(\mathrm{II})$ regeneration and to improve process efficiency [16]. Alternatively, high quantities of iron should be added to the contaminated water, which implies an increase in the consumption of the iron reagent and the generation of an iron oxyhydroxide sludge at the end of the treatment that needs to be managed.

The upgraded version of the Fenton process is the electrochemical generation of $\mathrm{H}_{2} \mathrm{O}_{2}$ and $\mathrm{Fe}(\mathrm{II})$, where both reagents are in-situ generated in an electrochemical cell. Moreover, $\mathrm{Fe}(\mathrm{II})$ can be regenerated by $\mathrm{Fe}(\mathrm{III})$ reduction on the cathode (Equation (4)), ensuring the continuity of the Fenton reaction (Equation (1)). This process is known as peroxyelectrocoagulation (PEC) [25-27]. The main reactions occurring at the oxygen/air diffusion cathode (Equations (3) and (4)) and at the Fe anode (Equation (5)) are detailed below:

$$
\mathrm{O}_{2(\mathrm{~g})}+2 \mathrm{H}^{+}{ }_{(\mathrm{aq})}+2 \mathrm{e}^{-} \rightarrow \mathrm{H}_{2} \mathrm{O}_{2(\mathrm{aq})}
$$




$$
\begin{gathered}
\mathrm{Fe}^{3+}{ }_{(\mathrm{aq})}+\mathrm{e}^{-} \rightarrow \mathrm{Fe}^{2+}{ }_{(\mathrm{aq})} \\
\mathrm{Fe}_{(\mathrm{s})} \rightarrow \mathrm{Fe}^{2+}{ }_{(\mathrm{aq})}+2 \mathrm{e}^{-}
\end{gathered}
$$

When an inert material is used as an anode instead of iron, Fe(II) must be added to the system. In this case, other oxidation reactions occur at the anode, depending on its materials. Partial water oxidation to hydroxyl radical (Equation (6)) takes places at non-active boron-doped diamond (BDD) anodes [28]. This process is called electro-Fenton (EF) [29].

$$
\mathrm{H}_{2} \mathrm{O}_{(\mathrm{l})} \rightarrow{ }^{\bullet} \mathrm{OH}_{(\mathrm{aq})}+\mathrm{H}^{+}(\mathrm{aq})+\mathrm{e}^{-}
$$

Although a dark electrochemical process to degrade erythromycin from water was studied, such as a microbial electro-Fenton system with an average removal efficiency of $89 \%$ in $48 \mathrm{~h}$ [30], oxidation of this compound using the EF and PEC processes has not yet been investigated. Again, solar light was chosen to increase the efficiency of the electrochemical treatment [31]. Approximately $69 \%$ of $165 \mathrm{mg} \mathrm{L}^{-1}$ erythromycin was mineralized by solar photo electro-Fenton process with $\mathrm{Pt} / \mathrm{Ti}$ anode, graphite-felt cathode, and applying the following conditions: $27.7 \mathrm{mg} \mathrm{L}^{-1} \mathrm{Fe}(\mathrm{II}), \mathrm{pH} \mathrm{3}$, a current density on cathode $\left(j_{\text {cathode }}\right)$ of $0.16 \mathrm{~mA} \mathrm{~cm}^{-2}$ and a current density on anode ( $\left.j_{\text {anode }}\right)$ of $32.8 \mathrm{~mA} \mathrm{~cm}^{-2}$ [31]. This study [31] also examined certain erythromycin transformation byproducts generated at intermediate $(30 \mathrm{~min})$ or elevated $(120 \mathrm{~min})$ treatment times of the solar photo electro-Fenton process.

Considering all this information, studying the removal of this emerging compound from water in Fenton-based processes in dark conditions was highly recommendable, given that they offer the opportunity of competitive industrial technologies with lower surface occupation and lower investment costs when compared to solar driven treatments [32].

The intention of this article is to describe how to answer this necessity, investigating the mineralization of erythromycin from ultrapure water by PEC and EF processes, comparing the influence of current density, oxygen flowrate injected into the cathode and $\mathrm{pH}$ on the process efficiency. The erythromycin concentration $\left(10 \mathrm{mg} \mathrm{L}^{-1}\right)$ used in the current work is higher than those potentially found in real effluents [11-15] in order to identify non-reported erythromycin degradation byproducts generated during the early stage of the treatment and to propose its degradation pathway. Finally, the most appropriate operational conditions detected in synthetic water were applied to treat a real effluent from the tertiary treatment of a municipal wastewater treatment plant (WWTP). The emerging compounds listed in the Watch List 2018 were quantified for this effluent and their degradation percentage, total mineralization, and the economic efficiency of the electrochemical process determined.

\section{Materials and Methods}

\subsection{Chemicals}

Erythromycin (purity > 99\%) was of reagent grade and supplied by Sigma Aldrich (St. Louis, MO, USA). Anhydrous $\mathrm{Na}_{2} \mathrm{SO}_{4}$ (used as background electrolyte) and $\mathrm{FeSO}_{4} \cdot 7 \mathrm{H}_{2} \mathrm{O}$ (used as catalyst during EF experiments) were of analytical grade and both were purchased from Scharlab S.L. (Sentmenat, Spain). Reagent grade 30\% $(w / w) \mathrm{H}_{2} \mathrm{O}_{2}$ was also supplied by Scharlab S.L. Analytical grade $96 \% \mathrm{H}_{2} \mathrm{SO}_{4}$ and $\mathrm{NaOH}$ pellets from Scharlab S.L. were used for the preparation of diluted solutions used for the $\mathrm{pH}$ adjustment. $1000 \mathrm{mg} \mathrm{L}^{-1} \mathrm{Ti}$ standard solution ( $\mathrm{TiSO}_{5} \times \mathrm{H}_{2} \mathrm{SO}_{4}$ ) from Sigma Aldrich and analytical grade $96 \% \mathrm{H}_{2} \mathrm{SO}_{4}$ were used to determine the $\mathrm{H}_{2} \mathrm{O}_{2}$ concentration.

Solutions were prepared with high-purity water from a Milli-Q Academic (Merck Life Science S.L, Madrid, Spain) system (resistivity $>18 \mathrm{M} \Omega \mathrm{cm}$, at $25^{\circ} \mathrm{C}$ ).

Acetonitrile $(\mathrm{ACN})$, methanol $(\mathrm{MeOH})$ and water, all LC-MS grade, were purchased from Scharlab S.L. Formic acid $\left(\mathrm{CH}_{2} \mathrm{O}_{2}\right)$ LC-MS grade were purchased from Fisher Scientific (Loughborough, Leicestershire, UK), and ammonium fluoride $\left(\mathrm{NH}_{4} \mathrm{~F}\right)$, dimethylsulfoxide (DMSO) LC-MS grade, phosphate buffered saline (PBS) and ammonium formate $\left(\mathrm{NH}_{4} \mathrm{HCO}_{2}\right)$ were supplied by Sigma-Aldrich. 
The standards to determine the compounds described in the EU Decision 2018/840 [5] were supplied by various companies. 17- $\alpha$-ethinylestradiol (EE2), 17 - $\beta$-estradiol (E2) and metaflumizone were supplied by Dr. Ehrenstorfer GmbH (Augsburg, Germany); estrone (E1) and erythromycin were supplied by Sigma-Aldrich; clarithromycin, azithromycin, methiocarb, imidacloprid, thiacloprid, thiametoxam, chlothianidin, acetamiprid and ciprofloxacin$\mathrm{HCl}$ were supplied by Neochema $\mathrm{GmbH}$ (Bodengeim, Germany) at a concentration of $10 \mathrm{mg} \mathrm{L}^{-1}$ with ACN; amoxicillin trihydrate was supplied by Toronto Research Chemicals (Toronto, ON, Canada).

Isotopically labelled compounds were used as internal standards (IS). 17- $\alpha$ ethinylestradiol-2,4,16,16-d4, 17- $\beta$-estradiol-2,4,16,16,17-d5, erythromycin-d3, estrone-2,416,16-d4, clarithromycin-d3, imidacloprid-d4, methiocarb-d3 were supplied by Neochema $\mathrm{GmbH}$ at a concentration of $10 \mathrm{mg} \mathrm{L}^{-1}$ in ACN; thiamethoxam-d4 (oxadiazine-d4) and chlothianidin-d3 (N'-methyl-d3) were supplied by Dr. Ehrenstorfer GmbH; acetamipridd3 (N-methyl-d3) (mixture of isomers) was supplied by CDN isotopes (Pointe-Claire, QC, Canada); and amoxicillin-d4 (major) was supplied by Toronto Research Chemical. Standard solutions were prepared in MeOH LC-MS grade, with the exception of amoxicillin trihydrate that it was prepared with DMSO. Calibration mixtures were prepared in water:MeOH $(1: 1, v / v)$.

\subsection{Instruments and Analytical Procedures}

Dissolved organic carbon (DOC), total inorganic carbon (TIC) and total nitrogen (TN) was monitored by an Multi N/C 3100 analyser (Analytik Jena, Jena, Germany). Reproducible values, within $\pm 2 \%$ accuracy, were obtained by injecting $50 \mu \mathrm{L}$ aliquots previously filtered by $0.45 \mu \mathrm{m}$ polyvinylidene fluoride (PVDF) membranes. Total and dissolved iron was measured by the spectrophotometric method based on Standard Method 3500-Fe-B [33]. A UV / Vis UV-2450 spectrophotometer (Shimadzu, Kyoto, Japan) was used to determine $\mathrm{H}_{2} \mathrm{O}_{2}$ concentrations from absorption of the $\mathrm{Ti}-\mathrm{H}_{2} \mathrm{O}_{2}$ coloured complex at $\lambda=410 \mathrm{~nm}$ [34], filtering previously $1 \mathrm{~mL}$ of samples by $0.45 \mu \mathrm{m}$ PVDF filters. A sensiION ${ }^{\mathrm{TM}} \mathrm{MM} 374 \mathrm{pH}$ meter and electrical conductivity meter (Hach Lange Spain, S.L.U., Hospitalet de Llobregat, Barcelona, Spain) was used to follow the values of $\mathrm{pH}$ and the conductivity.

For the determination of erythromycin and its transformation products, $100 \mu \mathrm{L}$ of water sample was mixed with $50 \mu \mathrm{L}$ of internal standard solution (erythromycin-d3) at a concentration of $1 \mathrm{mg} \mathrm{mL}^{-1}$ prepared in ultrapure water. The samples were diluted with $850 \mu \mathrm{L}$ of PBS to adjust the $\mathrm{pH}$ of the solution at 7.8 since erythromycin degradation is promoted at acidic $\mathrm{pH}$. Then, samples were vortexed, centrifuged for $5 \mathrm{~min}$ at $4{ }^{\circ} \mathrm{C}$ and $15,000 \mathrm{rpm}$ and transferred to a chromatographic vial for their analysis.

The chromatographic separation was performed on an UHPLC 1290 Infinity II Series coupled to a QTOF/MS 6550 Series, both from Agilent Technologies (Santa Clara, CA, USA). The chromatographic column was a Kinetex EVO C18 $(100 \times 2.1 \mathrm{~mm})$ from Phenomenex (Torrance, CA, USA) and the mobile phase was $100 \%$ water with $0.1 \%$ formic acid (A) and $100 \% \mathrm{ACN}(\mathrm{B})$. The gradient elution was as follows: $0-0.5 \mathrm{~min}$ (0\% B isocratic); 0.5-1.0 (0-15\% B); 1.0-10.0 (15-60\% B); 10.0-11.0 (60-100\% B); 11.0-13.0 (100\% B isocratic). The flowrate was set at $0.6 \mathrm{~mL} \mathrm{~min}^{-1}$, the column temperature at $25{ }^{\circ} \mathrm{C}$ and the injection volume was $2 \mu \mathrm{L}$.

The mass spectrometer operated in positive electrospray ionization (ESI) mode and the source parameters were as follows: gas temperature $\left(260{ }^{\circ} \mathrm{C}\right)$, gas flow $\left(11 \mathrm{~L} \mathrm{~min}^{-1}\right)$, sheath gas temperature $\left(350^{\circ} \mathrm{C}\right)$, sheath gas flow $\left(12 \mathrm{~L} \mathrm{~min}^{-1}\right)$, nebulizer (20 psi), capillary voltage $(5100 \mathrm{~V})$ and nozzle voltage $(500 \mathrm{~V})$. Data acquisition was carried out in full-scan over a mass-range of 100 to $1700 \mathrm{~m} / \mathrm{z}$ at 2.5 spectra/s and MS/MS spectra were performed at 15,30 and $45 \mathrm{eV}$.

The assignment of erythromycin was performed by direct comparison with the commercial standard, whereas the tentative identification of erythromycin degradation products was according to bibliography [16,35-39], exact mass, retention time and tandem mass 
spectra. These degradation products were semi-quantified using the erythromycin internal standard calibration curve. Additionally, erythromycin E and erythromycin F dehydrogenation TP-2 which have the same exact mass and retention time were semi-quantified by using their product ion spectra with the chromatographic peak of $748.4478 \rightarrow 574.3605$ and $748.4478 \rightarrow 590.3554$ transitions, respectively.

A solid phase extraction (SPE) procedure based on a previous publication [40] to analyze the compounds included in the Watch List 2018 was carried out. Oasis HLB SPE cartridges ( $3 \mathrm{~mL}, 400 \mathrm{mg}$ ) were supplied by Waters (Milford, MA, USA) and the extraction was performed on a Supelco Visiprep SPE Vacuum Manifold (Sigma Aldrich, Saint Louis, MI, USA). The cartridges were previously conditioned with successive volumes of $2 \mathrm{~mL}$ of $\mathrm{MeOH}$ and $2 \mathrm{~mL}$ of Milli-Q water. Then, $100 \mathrm{~mL}$ of wastewater samples, previously filtered through a $0.45 \mu \mathrm{m}$ nylon filter from Millipore (Burlington, MA, USA), were spiked with $0.1 \mathrm{~mL}$ of internal standard mixture at a concentration of $1 \mu \mathrm{g} \mathrm{mL} \mathrm{L}^{-1}$ and loaded to the SPE cartridge. After this, the cartridges were washed with $2 \mathrm{~mL}$ of Milli-Q water and dried under vacuum system. The compounds were eluted with $1.5 \mathrm{~mL}$ of $\mathrm{MeOH}$. The eluates were evaporated under a nitrogen flow and reconstituted with $200 \mu \mathrm{L}$ of $\mathrm{MeOH}$ :water $(80: 20, v / v)$ and transferred to glass vials for LC-MS/MS analysis.

The chromatographic analysis of the compounds of the Watch List 2018 was performed on and UHPLC 1290 Series coupled to a triple quadrupole mass spectrometer (QqQ) 6490 Series, both from Agilent Technologies.

The compounds included in this study were determined in two different chromatographic methods depending on their ESI mode (positive or negative). In both cases, the chromatographic separation was performed using a Acquity UPLC BEH C18, $1.7 \mu \mathrm{m}$ $(100 \times 2.1 \mathrm{~mm})$ from Waters. The group of compounds determined on negative ESI mode (ESI-), corresponding to estrogens (detailed in Table 1), were separated using as a mobile phase of $100 \%$ water with $5 \mathrm{mmol} \mathrm{L}^{-1}$ of ammonium fluoride (A) and $100 \% \mathrm{MeOH}$ (B). The gradient elution was as follows: $0-1 \mathrm{~min}(5 \% \mathrm{~B}$ isocratic); $1-2 \min (5-50 \% \mathrm{~B}), 2-9 \min (50-$ $65 \% \mathrm{~B}), 9-10 \mathrm{~min}(65-98 \% \mathrm{~B}), 10-12 \mathrm{~min}$ (98\% B isocratic). The flowrate was set at $0.3 \mathrm{~mL}$ $\min ^{-1}$, the column temperature at $40^{\circ} \mathrm{C}$ and the injection volume was $2 \mu \mathrm{L}$. The source parameters were gas temperature $\left(250^{\circ} \mathrm{C}\right)$, gas flow $\left(16 \mathrm{~L} \mathrm{~min}^{-1}\right)$, sheath gas temperature $\left(375^{\circ} \mathrm{C}\right)$, sheath gas flow $\left(12 \mathrm{~L} \mathrm{~min}^{-1}\right)$, nebulizer (40 psi), capillary voltage $(3000 \mathrm{~V})$ and nozzle voltage $(1000 \mathrm{~V})$. Quantification of compounds was performed by internal standard calibration using multiple reaction monitoring acquisition, as detailed in Table 1.

The other compounds described in the Watch List 2018 (detailed Table 1) were determined by positive ESI (ESI+). The compounds were separated using a mobile phase consisting on water:MeOH (98:2, v/v) with $0.1 \%$ of formic acid (A) and MeOH:water (99:1) with $0.1 \%$ of formic acid and $10 \mathrm{mmol} \mathrm{L}^{-1}$ of ammonium formate (B). The gradient elution was as follows: $0-1 \mathrm{~min}(0 \% \mathrm{~B}$ isocratic); $1-6 \mathrm{~min}(0-50 \% \mathrm{~B}), 6-8.5 \mathrm{~min}(50-55 \% \mathrm{~B}), 8.5-$ $11.5 \mathrm{~min}(55-75 \% \mathrm{~B}), 11.5-13.5 \mathrm{~min}$ (75-85\% B), $13.5-19.0$ (85\% B isocratic), $19.0-19.3 \mathrm{~min}$ (85-100\% B), 19.3-21.3 min (100\% B isocratic), 21.3-21.4 min (100-0\% B), 21.4-23.4 min ( $0 \% \mathrm{~B}$ isocratic). The flowrate was set at $0.5 \mathrm{~mL} \mathrm{~min}^{-1}$, the column temperature at $40{ }^{\circ} \mathrm{C}$ and the injection volume was $2 \mu \mathrm{L}$. The source parameters were gas temperature $\left(180^{\circ} \mathrm{C}\right)$, gas flow $\left(20 \mathrm{~L} \mathrm{~min}^{-1}\right)$, sheath gas temperature $\left(225^{\circ} \mathrm{C}\right)$, sheath gas flow $\left(11 \mathrm{~L} \mathrm{~min}^{-1}\right)$, nebulizer $(40 \mathrm{psi})$, capillary voltage $(4500 \mathrm{~V})$ and nozzle voltage $(0 \mathrm{~V})$. Quantification of compounds was performed by internal standard calibration using multiple reaction monitoring acquisition, as detailed in Table 1. 
Table 1. Detailed multiple reaction monitoring transitions and retention time for each analyte listed in the EU Decision 2018/840.

\begin{tabular}{|c|c|c|c|c|c|c|c|c|}
\hline Compound & $\begin{array}{c}\text { Retention } \\
\text { Time (min) }\end{array}$ & ESI & $\begin{array}{c}\text { Quantitative } \\
\text { Transition }(\mathrm{m} / \mathrm{z})\end{array}$ & $\begin{array}{c}\text { Qualitative } \\
\text { Transition } \\
(m / z)\end{array}$ & $\begin{array}{l}\text { Collision } \\
\text { Energy (V) }\end{array}$ & $r^{2}$ & $\begin{array}{l}\text { Quantification } \\
\text { Limit (MLOQ) } \\
\quad\left(\operatorname{ng~L}^{-1}\right)\end{array}$ & $\begin{array}{c}\text { Detection } \\
\text { Limit (MLOD) } \\
\left(\mathrm{ng} \mathrm{L}^{-1}\right)\end{array}$ \\
\hline $17-\beta$-Estradiol-d5 & 8.70 & ESI (-) & $276.2 \rightarrow 147.1$ & $276.2 \rightarrow 187.2$ & $49 / 41$ & & & \\
\hline $17-\beta$-Estradiol (E2) & 8.75 & ESI (-) & $271.2 \rightarrow 145.1$ & $271.2 \rightarrow 183.1$ & $45 / 49$ & 0.99 & 1 & 0.3 \\
\hline Estrone-d4 & 8.76 & ESI $(-)$ & $273.1 \rightarrow 147.1$ & $273.1 \rightarrow 145.0$ & $49 / 60$ & & & \\
\hline Estrone (E1) & 8.79 & ESI (-) & $269.1 \rightarrow 145.1$ & $269.1 \rightarrow 143.1$ & $41 / 60$ & 0.99 & 1 & 0.3 \\
\hline 17- $\alpha$-Ethinylestradiol-d5 & 8.90 & ESI (-) & $299.2 \rightarrow 147.1$ & $299.2 \rightarrow 269.1$ & $33 / 53$ & & & \\
\hline $\begin{array}{l}\text { 17- } \alpha \text {-Ethinylestradiol } \\
\text { (EE2) }\end{array}$ & 8.85 & ESI $(-)$ & $295.2 \rightarrow 145.2$ & $295.17 \rightarrow 142.9$ & $49 / 60$ & 0.99 & 1 & 0.03 \\
\hline Amoxicillin-d4 & 2.71 & ESI $(+)$ & $370.1 \rightarrow 114.0$ & $370.1 \rightarrow 353.3$ & $21 / 9$ & & & \\
\hline Amoxicillin & 2.73 & ESI $(+)$ & $366.1 \rightarrow 114.0$ & $366.1 \rightarrow 349.2$ & $18 / 4$ & 0.95 & 1 & 0.3 \\
\hline Thiamethoxam-d4 & 4.78 & ESI $(+)$ & $296.1 \rightarrow 215.0$ & $296.1 \rightarrow 183.0$ & $5 / 21$ & & & \\
\hline Thiamethoxam & 4.82 & ESI $(+)$ & $292.0 \rightarrow 210.9$ & $292.0 \rightarrow 180.8$ & $9 / 21$ & 0.99 & 1 & 0.3 \\
\hline Ciprofloxacin & 5.39 & ESI $(+)$ & $332.1 \rightarrow 231.0$ & $332.0 \rightarrow 314.2$ & $45 / 17$ & 0.99 & 1 & 0.3 \\
\hline Clothianidin-d3 & 4.47 & ESI (+) & $253.0 \rightarrow 172.0$ & $253.0 \rightarrow 131.8$ & $9 / 21$ & & & \\
\hline Clothianidin & 4.48 & ESI (+) & $250.0 \rightarrow 131.9$ & $250.0 \rightarrow 169.1$ & $13 / 9$ & 0.99 & 1 & 0.3 \\
\hline Imidacloprid-d4 & 5.49 & ESI $(+)$ & $260.1 \rightarrow 179.2$ & $260.1 \rightarrow 213.1$ & $13 / 9$ & & & \\
\hline Imidacloprid & 5.52 & ESI (+) & $256.1 \rightarrow 175.0$ & $256.1 \rightarrow 209.1$ & 1721 & 0.99 & 10 & 3 \\
\hline Acetamiprid-d3 & 5.94 & ESI (+) & $226.1 \rightarrow 126.1$ & $226.1 \rightarrow 59.2$ & $21 / 13$ & & & \\
\hline Acetamiprid & 5.95 & ESI $(+)$ & $223.1 \rightarrow 126.1$ & $223.1 \rightarrow 56.0$ & $17 / 13$ & 0.99 & 1 & 0.3 \\
\hline Thiacloprid & 6.42 & ESI (+) & $253.0 \rightarrow 125.9$ & $253.0 \rightarrow 98.9$ & $21 / 53$ & 0.99 & 1 & 0.3 \\
\hline Azithromycin & 7.25 & ESI (+) & $749.5 \rightarrow 82.9$ & $749.5 \rightarrow 591.3$ & $60 / 33$ & 0.99 & 1 & 0.3 \\
\hline Erythromycin-d3 & 9.12 & ESI $(+)$ & $737.5 \rightarrow 161.0$ & $737.5 \rightarrow 82.9$ & $37 / 60$ & & & \\
\hline Erythromycin & 9.12 & ESI $(+)$ & $734.4 \rightarrow 158.1$ & $734.4 \rightarrow 83.1$ & $37 / 60$ & 0.99 & 6 & 1.8 \\
\hline Methiocarb-d3 & 10.36 & ESI (+) & $229.1 \rightarrow 169.1$ & $229.1 \rightarrow 121.0$ & $9 / 17$ & & & \\
\hline Methiocarb & 10.38 & ESI $(+)$ & $226.1 \rightarrow 169.0$ & $226.1 \rightarrow 121.1$ & $17 / 9$ & 0.99 & 20 & 6 \\
\hline Clarithromycin-d3 & 10.84 & ESI (+) & $751.5 \rightarrow 161.1$ & $751.5 \rightarrow 83.1$ & $25 / 57$ & & & \\
\hline Clarithromycin & 10.86 & ESI (+) & $748.5 \rightarrow 158.2$ & $748.5 \rightarrow 83.1$ & $37 / 60$ & 0.99 & 1 & 0.3 \\
\hline Metaflumizone & 14.60 & ESI $(+)$ & $507.1 \rightarrow 178.2$ & $507.1 \rightarrow 87.0$ & $33 / 25$ & 0.99 & 6 & 1.8 \\
\hline
\end{tabular}

\subsection{Experimental Setup and Operational Conditions}

$1 \mathrm{~L}$ of $10 \mathrm{mg} \mathrm{L}^{-1}$ erythromycin (Milli-Q water) and $0.05 \mathrm{M} \mathrm{Na}_{2} \mathrm{SO}_{4}$ (background electrolyte) was treated by EF and PEC processes by continuously recirculating the solution from a reservoir (cylindrical Pyrex glass reactor of $2 \mathrm{~L}$ and $100 \mathrm{~mm}$ of internal diameter) to a mono-compartment filter-press cell at $20 \mathrm{~L} \mathrm{~h}^{-1}$. Figure 1 shows a scheme of the experimental system.

The electrochemical cell was integrated by an anode and an oxygen-diffusion cathode, both of $100 \mathrm{~mm}$ of diameter, separated $5 \mathrm{~mm}$. Two anode materials were tested: $\mathrm{Fe}$ and boron doped diamond coated on silicon (BDD/Si), the later with a resistivity of $100 \mathrm{~m} \Omega \cdot \mathrm{cm}$, and with a $2.5 \mu \mathrm{m}$ BDD coating $([\mathrm{B}]=700 \mathrm{ppm})\left(\mathrm{NeoCoat}{ }^{\circledR}\right.$, Eplatures-Grise, La Chaux-deFonds, Switzerland). The oxygen-diffusion cathode was composed by a titanium diffuser, used as electrode collector, and an activated carbon cloth with polytetrafluoroethylene (PTFE) (Fuel Cells Etc, College Station, TX, USA) that promotes the reduction of oxygen to $\mathrm{H}_{2} \mathrm{O}_{2}$. Oxygen was fed to the cathode at an overpressure of 4.5 bar, testing two different flowrates: $0.8 \mathrm{~L} \mathrm{~min}^{-1}$ and $2.0 \mathrm{~L} \mathrm{~min}^{-1}$. The carbon cloth of the oxygen-diffusion cathode was previously activated by electrolyzing $1 \mathrm{~L}$ of $0.05 \mathrm{M} \mathrm{Na}_{2} \mathrm{SO}_{4}$ at $150 \mathrm{~mA} \mathrm{~cm}^{-2}$ and $\mathrm{pH}$ 2.8 during $1 \mathrm{~h}$. 


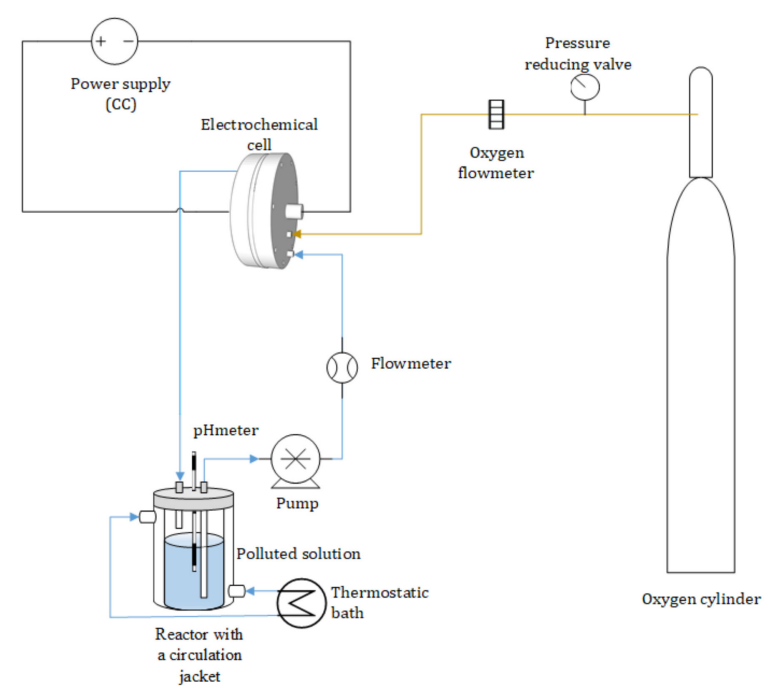

Figure 1. Scheme of the experimental system for the EF and PEC processes.

Experiments were carried out under galvanostatic conditions, using a power supply of Elektro-Automatik GmbH \& Co (Viersen, Germany), and directly measuring the potential difference, assessing the influence of two current densities on anode $\left(j_{\text {anode }}\right): 5 \mathrm{~mA} \mathrm{~cm}^{-2}$ and $10 \mathrm{~mA} \mathrm{~cm}^{-2}$. These current densities were chosen considering that the most suitable $j_{\text {anode }}=16.7 \mathrm{~mA} \mathrm{~cm}^{-2}$ for the EF treatment of a complex pharmaceutical mixture [41], therefore smaller current densities were selected to study the treatment of a synthetic water and an urban wastewater.

Solutions were maintained at $25{ }^{\circ} \mathrm{C}$ with a water circulation jacket connected to an external thermostat. The $\mathrm{pH}$ was also kept constant throughout the trials. Three different pHs were evaluated: 2.8 (optimal $\mathrm{pH}$ for the Fenton process [42,43]), near neutral $\mathrm{pH}(5.0)$ and neutral $\mathrm{pH}(7.0)$, the two last were studied to reduce the use of acid reagent to adjust the $\mathrm{pH}$. During EF experiments, the initial concentration of the catalyst, added externally to the water, was $10 \mathrm{mg} \mathrm{L}^{-1} \mathrm{Fe}(\mathrm{II})$. This value was chosen considering that the maximum iron concentration of wastewaters to be discharged in the sewer is $10 \mathrm{mg} \mathrm{L}^{-1}$ in Catalonia [44]. Therefore, no additional posttreatments to precipitate iron would be needed for treating a wastewater by the $\mathrm{EF}$ process at $10 \mathrm{mg} \mathrm{L}^{-1} \mathrm{Fe}(\mathrm{II})$.

Finally, the electrochemical treatment was applied to a real effluent from a sand filter of the tertiary treatment of an urban WWTP using the optimal operational conditions identified for treating synthetic polluted water. All the experimental conditions are summarized in Table 2.

Table 2. Summary of the experimental conditions.

\begin{tabular}{|c|c|c|c|c|c|}
\hline $\begin{array}{l}\text { Experiment } \\
\text { Conditions }\end{array}$ & Type of Water & $\begin{array}{l}\text { Anode } \\
\text { Type }\end{array}$ & $\begin{array}{c}j_{\text {anode }} \\
\left(\mathrm{mA} / \mathrm{cm}^{2}\right)\end{array}$ & $\begin{array}{l}\text { Oxygen } \\
\text { Flowrate } \\
\text { (L/min) }\end{array}$ & $\mathrm{pH}$ \\
\hline EF-1 & \multirow{8}{*}{$\begin{array}{l}\text { Ultrapure water. } \\
10 \mathrm{mg} \mathrm{L}^{-1} \text { erythromycin and } \\
0.05 \mathrm{M} \mathrm{Na}_{2} \mathrm{SO}_{4}\end{array}$} & BDD & 5 & 2.0 & 2.8 \\
\hline EF-2 & & BDD & 10 & 2.0 & 2.8 \\
\hline PEC-1 & & $\mathrm{Fe}$ & 5 & 2.0 & 2.8 \\
\hline PEC-2 & & $\mathrm{Fe}$ & 10 & 2.0 & 2.8 \\
\hline PEC-3 & & $\mathrm{Fe}$ & 5 & 0.8 & 2.8 \\
\hline PEC-4 & & $\mathrm{Fe}$ & 10 & 0.8 & 2.8 \\
\hline PEC-5 & & $\mathrm{Fe}$ & 5 & 2.0 & 5.0 \\
\hline PEC-6 & & $\mathrm{Fe}$ & 5 & 2.0 & 7.0 \\
\hline PEC-7 & $\begin{array}{l}\text { Effluent from a tertiary treatment } \\
\text { of an urban WWTP }\end{array}$ & $\mathrm{Fe}$ & 5 & 2.0 & 2.8 \\
\hline
\end{tabular}




\section{Results and Discussion}

\subsection{Effect of the Anode Material and the Current Density}

Electro-Fenton (using a BDD anode) and PEC (using a Fe anode) were compared applying two different current densities (5 and $10 \mathrm{~mA} \mathrm{~cm}^{-2}$ ), at $\mathrm{pH} 2.8$ and injecting $2.0 \mathrm{~L} \mathrm{~min}^{-1} \mathrm{O}_{2}$ into the cathode. Figure 2 plots the evolution of the DOC and the $\left[\mathrm{H}_{2} \mathrm{O}_{2}\right]$ as a function of the applied charge.
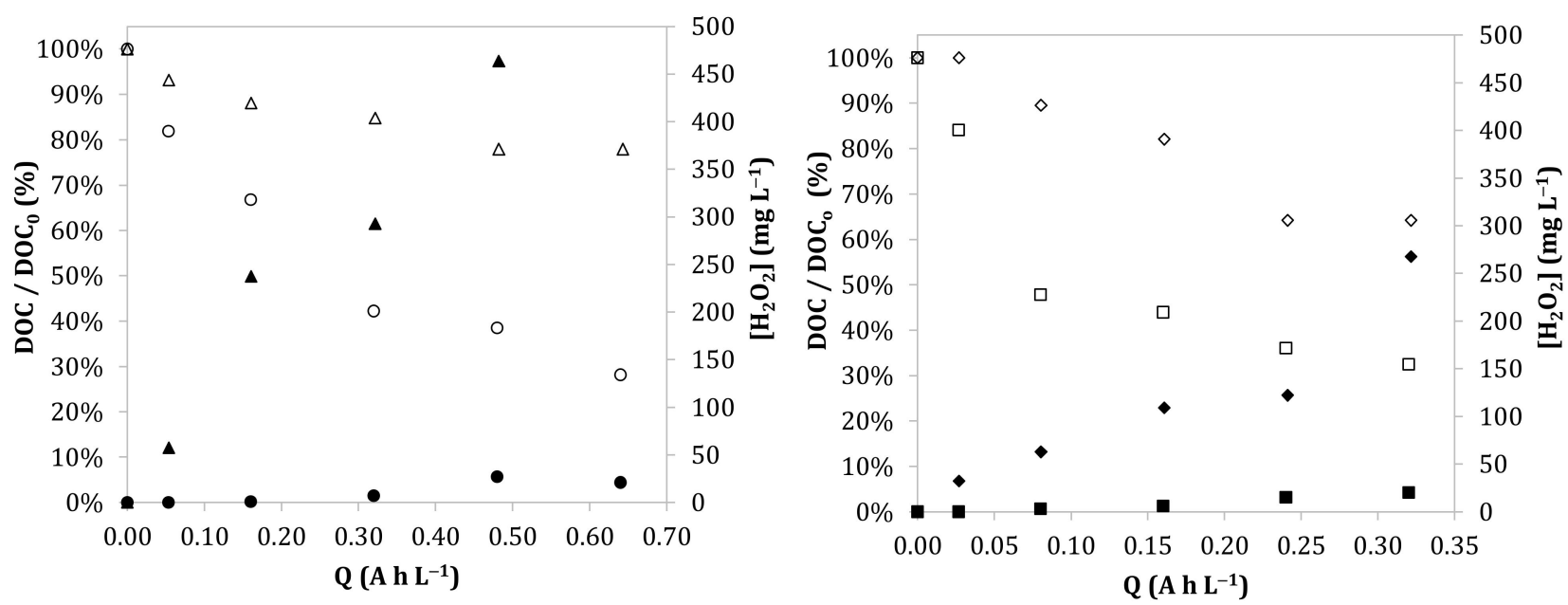

Figure 2. Evolution of dissolved organic carbon (DOC) $(\triangle, \bigcirc, \diamond, \square)$ and $\left[\mathrm{H}_{2} \mathrm{O}_{2}\right]$ remained in water $(\boldsymbol{\Lambda}, \bullet, \bullet, \mathbf{\square})$ through the applied charge in $1 \mathrm{~L}$ of $10 \mathrm{mg} \mathrm{L}^{-1}$ erythromycin and $0.05 \mathrm{M} \mathrm{Na}_{2} \mathrm{SO}_{4}$ (ultrapure water) treated by the EF and PEC processes at $25^{\circ} \mathrm{C}, 2 \mathrm{~L} \mathrm{~min}^{-1} \mathrm{O}_{2}$ and $\mathrm{pH}=2.8$ under the following conditions: $(\triangle, \mathbf{\Delta})$ BDD anode, $10 \mathrm{~mA} \mathrm{~cm}^{-2}($ left graphic); $(\bigcirc, \bullet)$ Fe anode, $10 \mathrm{~mA} \mathrm{~cm}^{-2}$ (left graphic); $(\diamond, \diamond) \mathrm{BDD}$ anode, $5 \mathrm{~mA} \mathrm{~cm}^{-2}$ (right graphic); ( $\square$, $\left.\mathbf{\square}\right)$ Fe anode, $5 \mathrm{~mA} \mathrm{~cm}^{-2}$ (right graphic).

The mineralization of the organic matter was defined as the complete oxidation of the organic molecules into $\mathrm{CO}_{2}$, inorganic ions, and water, and it was determined by the analysis of the total dissolved organic carbon (DOC) throughout the treatment time.

The mineralization rates of the $\mathrm{EF}\left(k_{\mathrm{EF}}\right)$ and the PEC $\left(k_{\mathrm{PEC}}\right)$ processes under studied conditions followed a pseudo-first order kinetics (Equation (7)):

$$
\ln \left(\mathrm{C} / \mathrm{C}_{0}\right) / \mathrm{t}=k
$$

where $\mathrm{C}$ and $\mathrm{C}_{0}$ represent the final and initial erythromycin concentration, respectively, and $\mathrm{t}$ the treatment time.

Mineralization constant rates obtained by the EF process under the studied conditions were $k_{\mathrm{EF} 1}\left(5 \mathrm{~mA} \mathrm{~cm}{ }^{-2}\right)=0.008 \mathrm{~s}^{-1}$ and $k_{\mathrm{EF} 2}\left(10 \mathrm{~mA} \mathrm{~cm}{ }^{-2}\right)=0.004 \mathrm{~s}^{-1}$. These values were significantly lower than those achieved when iron is used as anode (PEC process), where constant rate increased to $0.020 \mathrm{~s}^{-1}$ for both current densities. The mineralization reached in EF process was approximately $35 \%$, whereas it was increased at $70 \%$ during PEC treatment, after applying $0.32 \mathrm{~A} \mathrm{~h} \mathrm{~L}^{-1}$.

As depicted in the Figure 2, the remained $\mathrm{H}_{2} \mathrm{O}_{2}$ concentrations after $1 \mathrm{~h}$ of the EF treatment were around $260 \mathrm{mg} \mathrm{L}^{-1}$ and $460 \mathrm{mg} \mathrm{L}^{-1}$ at 5 and $10 \mathrm{~mA} \mathrm{~cm}^{-2}$ when 0.32 and $0.64 \mathrm{~A} \mathrm{~h} \mathrm{~L} \mathrm{~L}^{-1}$ were applied, respectively.

These experimental $\mathrm{H}_{2} \mathrm{O}_{2}$ concentrations remained throughout the EF were similar than the theoretical ones generated. This fact indicates that only small quantities of $\mathrm{H}_{2} \mathrm{O}_{2}$ reacted with the $10 \mathrm{mg} \mathrm{L}^{-1} \mathrm{Fe}(\mathrm{II})$. Moreover, it should be considered that an excessive $\mathrm{H}_{2} \mathrm{O}_{2}$ concentration acts as ${ }^{\bullet} \mathrm{OH}$ scavenger (Equation (8)) reducing the efficiency for organic matter oxidation:

$$
\bullet \mathrm{OH}_{(\mathrm{aq})}+\mathrm{H}_{2} \mathrm{O}_{2(\mathrm{aq})} \rightarrow \mathrm{HO}_{2}{ }_{(\mathrm{aq})}+\mathrm{H}_{2} \mathrm{O}_{(\mathrm{l})} k=1.7-4.5 \times 10^{7} \mathrm{M}^{-1} \mathrm{~s}^{-1}
$$


Although $\bullet \mathrm{OH}$ reacts with organic molecules with rate constants of $10^{9}-10^{10} \mathrm{M}^{-1} \mathrm{~s}^{-1}$ [45], it reacts with $\mathrm{H}_{2} \mathrm{O}_{2}$ at a 100-1000 times lower rate constant $\left(k=1.7-4.5 \times 10^{7} \mathrm{M}^{-1} \mathrm{~s}^{-1}\right.$ [24]) as the reaction rate depends on the initial concentration of organic matter and $\mathrm{H}_{2} \mathrm{O}_{2}$. Considering the initial erythromycin concentration $\left(10 \mathrm{mg} \mathrm{L}^{-1}\right)$ and the remained $\mathrm{H}_{2} \mathrm{O}_{2}$ concentrations of this work, the molar $\mathrm{H}_{2} \mathrm{O}_{2}$ /erythromycin ratio was higher than 100 after the $15 \mathrm{~min}$ and $5 \mathrm{~min}$ of the $\mathrm{EF}$ treatment at 5 and $10 \mathrm{~mA} \mathrm{~cm}^{-2}$, respectively. Therefore, after these treatment times, hydroxyl radical is expected to react preferentially with $\mathrm{H}_{2} \mathrm{O}_{2}$ instead of organic matter. This fact can explain why the $k_{\mathrm{EF} 2}\left(10 \mathrm{~mA} \mathrm{~cm}{ }^{-2}\right)=0.004 \mathrm{~s}^{-1}$ was lower than $k_{\mathrm{EF} 1}\left(5 \mathrm{~mA} \mathrm{~cm}{ }^{-2}\right)=0.008 \mathrm{~s}^{-1}$.

In comparison, most $\mathrm{H}_{2} \mathrm{O}_{2}$ was consumed during PEC experiments, remaining around $20 \mathrm{mg} \mathrm{L}^{-1}$ at the end of the trials. This is a consequence of the higher Fe concentrations generated during PEC (theoretical concentrations of around $220 \mathrm{mg} \mathrm{L}^{-1}$ and $440 \mathrm{mg} \mathrm{L}^{-1}$ $\mathrm{Fe}(\mathrm{III})$ at 0.32 and $0.64 \mathrm{~A} \mathrm{~h} \mathrm{~L}^{-1}$, respectively) compared to that used during EF trials (10 $\mathrm{mg} \mathrm{L}^{-1} \mathrm{Fe}(\mathrm{II})$ ). Indeed, in the PEC experimental conditions, the molar $\mathrm{H}_{2} \mathrm{O}_{2} / \mathrm{Fe}$ (III) ratios were around 1.7-2.0, indicating that higher iron concentration resulted in higher reactivity with the hydrogen peroxide. Consequently, higher theoretical concentration of hydroxyl radical (Equation (1)) and other reactive oxygen species that can attack organic compounds can be obtained. Nonetheless, elevated concentrations of Fe(II) or Fe(III) can also act as scavenger of ${ }^{\bullet} \mathrm{OH}$, following Equations (9) and (10) [24]:

$$
\begin{array}{cc}
\mathrm{Fe}^{2+}{ }_{(\mathrm{aq})}+{ }^{\bullet} \mathrm{OH}_{(\mathrm{aq})} \rightarrow \mathrm{Fe}^{3+}{ }_{(\mathrm{aq})}+\mathrm{OH}^{-}{ }_{(\mathrm{aq})} & k=2.5-5.1 \times 10^{8} \mathrm{M}^{-1} \mathrm{~s}^{-1} \\
\mathrm{Fe}^{3+}{ }_{(\mathrm{aq})}+{ }^{\bullet} \mathrm{OH}_{(\mathrm{aq})} \rightarrow \mathrm{Fe}^{4+}{ }_{(\mathrm{aq})}+\mathrm{OH}^{-}{ }_{(\mathrm{aq})} & k=7.9 \times 10^{7} \mathrm{M}^{-1} \mathrm{~s}^{-1}
\end{array}
$$

After $15 \mathrm{~min}$ and $8 \mathrm{~min}$ of PEC treatment at 5 and $10 \mathrm{~mA} \mathrm{~cm}^{-2}$, respectively, the molar ratio $\mathrm{Fe}(\mathrm{III})$ /erythromycin was higher than 100 , therefore the ${ }^{\bullet} \mathrm{OH}$ starts to preferentially react with $\mathrm{Fe}(\mathrm{II})$ or $\mathrm{Fe}(\mathrm{III})$ instead of organic matter.

Moreover, it should be also considered that at elevated concentrations of Fe(III) (higher than $0.6 \mathrm{mg} \mathrm{L}^{-1}$ ) ferric oxyhydroxides start to precipitate at $\mathrm{pH}=2.8$ [46], whereas $\mathrm{Fe}(\mathrm{II})$ remains in solution at this $\mathrm{pH}$. Related to this, the percentage of dissolved versus total iron was around $100-85 \%$ throughout the PEC treatment at $5 \mathrm{~mA} \mathrm{~cm}{ }^{-2}$ whereas this value decreased to $75-40 \%$ at $10 \mathrm{~mA} \mathrm{~cm}{ }^{-2}$. These results indicate that most iron was dissolved at $5 \mathrm{~mA} \mathrm{~cm}^{-2}$ and $\mathrm{pH} 2.8$. The quantity of dissolved iron at both current densities were similar, thereby contributing in a similar way to the Fenton (Equation (1)) and Fentonlike (Equation (2)) reactions. Dissolved iron can be associated to ferrous cationic species, whereas ferric oxyhydroxides would be associated to iron precipitated.

All these reasons explain the no significant differences observed with the rate constants for both current densities $\left(k_{\mathrm{PEC}}=0.02 \mathrm{~s}^{-1}\right)$ tested during PEC trials.

These results demonstrate that, in the studied conditions, the PEC is more recommendable than the EF process in terms of both mineralization rate and electricity consumption. After applying 0.32 and $0.64 \mathrm{~A} \mathrm{~h} \mathrm{~L}^{-1}$, the electricity consumptions for BDD electrodes (EF) were around $3.7 \mathrm{kWh} \mathrm{m}^{-3}$ and $7.9 \mathrm{kWh} \mathrm{m}^{-3}$, whereas they were reduced to $0.3 \mathrm{kWh} \mathrm{m}^{-3}$ and $0.6 \mathrm{kWh} \mathrm{m}^{-3}$ when Fe was used as anode (PEC), respectively. This means a reduction of almost 12 -fold in the electricity costs by using Fe anodes.

Therefore, the PEC treatment was selected to study the influence of oxygen flowrate injected into the cathode.

\subsection{Effect of the Oxygen Flowrate}

The influence of two different oxygen flowrates $\left(0.8 \mathrm{~L} \mathrm{~min}^{-1} \mathrm{O}_{2}\right.$ and $\left.2.0 \mathrm{~L} \mathrm{~min}^{-1} \mathrm{O}_{2}\right)$ to the mineralization efficiency was studied by carrying out the PEC treatment applying two different current densities ( 5 and $10 \mathrm{~mA} \mathrm{~cm}^{-2}$ ), at $\mathrm{pH}$ 2.8. Results are plotted in Figure 3. 

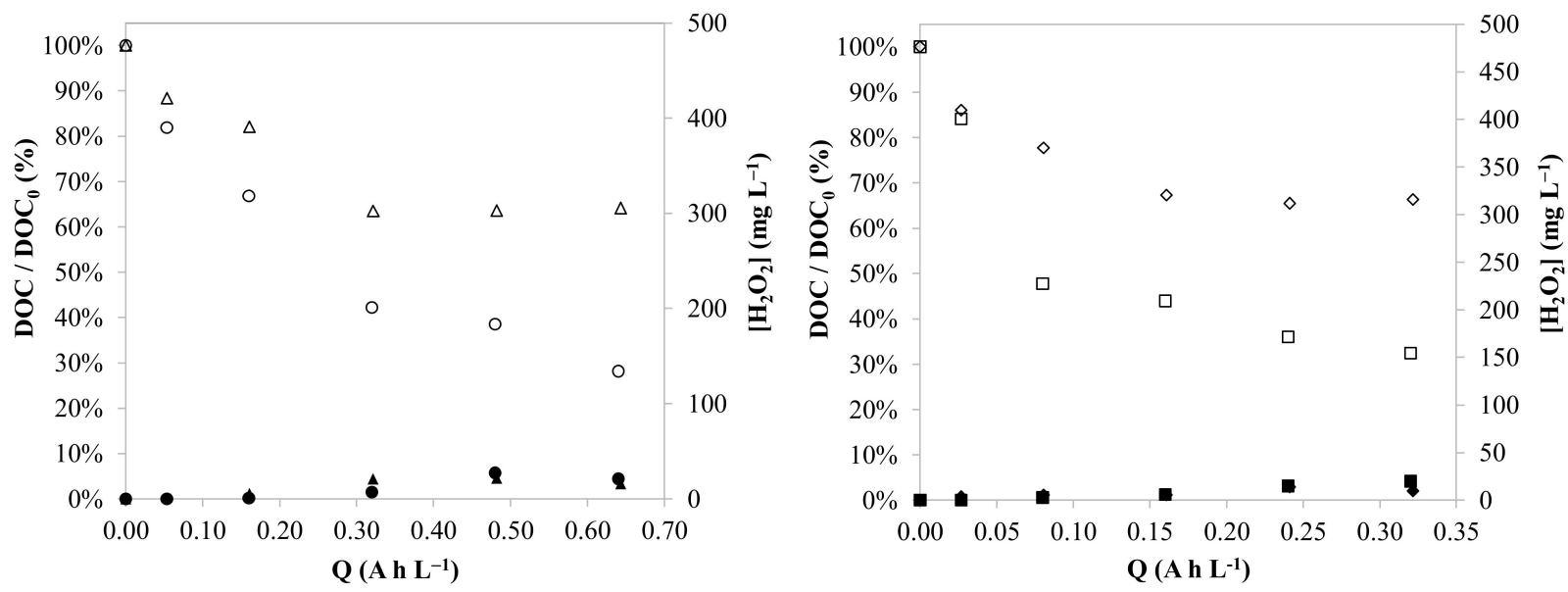

Figure 3. Evolution of DOC $(\bigcirc, \triangle, \square, \diamond)$ and $\left[\mathrm{H}_{2} \mathrm{O}_{2}\right]$ remained in water $(\bullet, \boldsymbol{\Delta}, \mathbf{\square}, \diamond)$ through the applied charge in $1 \mathrm{~L}$ of $10 \mathrm{mg} \mathrm{L}^{-1}$ erythromycin and $0.05 \mathrm{M} \mathrm{Na}_{2} \mathrm{SO}_{4}$ (ultrapure water) treated by the PEC process at $25^{\circ} \mathrm{C}, \mathrm{pH}=2.8, \mathrm{under}$ the following conditions: $(\bigcirc, \bullet) 10 \mathrm{~mA} \mathrm{~cm}^{-2}$ at $2 \mathrm{~L} \mathrm{~min}^{-1} \mathrm{O}_{2}$ (left graphic); $(\triangle, \Delta) 10 \mathrm{~mA} \mathrm{~cm}{ }^{-2}$ at $0.8 \mathrm{~L} \mathrm{~min}^{-1} \mathrm{O}_{2}(\mathbf{l e f t}$ graphic); ( $\square, \mathbf{\square}) 5 \mathrm{~mA} \mathrm{~cm}^{-2}$ at $2 \mathrm{~L} \mathrm{~min}^{-1} \mathrm{O}_{2}$ (right graphic); and $(\diamond, \diamond) 5 \mathrm{~mA} \mathrm{~cm}^{-2}$ at $0.8 \mathrm{~L} \mathrm{~min}^{-1} \mathrm{O}_{2}$ (right graphic).

When injecting $0.8 \mathrm{~L} \mathrm{~min}^{-1} \mathrm{O}_{2}$, the mineralization kinetics followed a pseudo-first order constant during the first $30 \mathrm{~min}$ of treatment, being the constant rate of $0.013 \mathrm{~s}^{-1}$ for 5 and $10 \mathrm{~mA} / \mathrm{cm}^{-2}$. The kinetics mineralization decreased at $0.8 \mathrm{~L} \mathrm{~min}^{-1} \mathrm{O}_{2}\left(0.013 \mathrm{~s}^{-1}\right)$ compared with the value obtained at $2.0 \mathrm{~L} \mathrm{~min}^{-1} \mathrm{O}_{2}\left(0.020 \mathrm{~s}^{-1}\right)$. This fact can be associated to the concentration of dissolved oxygen. With $2.0 \mathrm{~L} \mathrm{~min}^{-1} \mathrm{O}_{2}$ injected into the cathode, continuous oxygen saturation in water can be obtained, resulting in more dissolved oxygen available to produce $\mathrm{H}_{2} \mathrm{O}_{2}$.

No significant differences on mineralization rates between the studied current densities $\left(5\right.$ and $\left.10 \mathrm{~mA} / \mathrm{cm}^{-2}\right)$ were found in any of the tested oxygen flowrates $(0.8$ and $2.0 \mathrm{~L} \mathrm{~min}^{-1} \mathrm{O}_{2}$ ). The electricity consumption of the electrochemical cell also followed a similar pattern for both oxygen flowrates.

Therefore, the PEC process at $5 \mathrm{~mA} \mathrm{~cm}{ }^{-2}$ applying $2.0 \mathrm{~L} \mathrm{~min}^{-1} \mathrm{O}_{2}$ was chosen to study the influence of the $\mathrm{pH}$ on the process efficiency.

\subsection{Effect of the $p H$}

The influence of the $\mathrm{pH}$ on the efficiency of the PEC treatment was also studied. The results obtained are depicted in Figure 4.

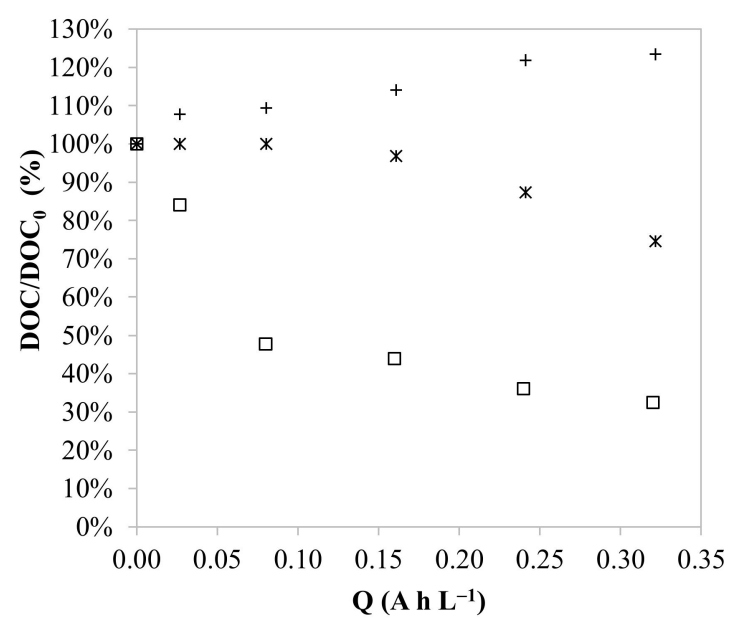

Figure 4. Evolution of DOC through the applied charge in $1 \mathrm{~L}$ of $10 \mathrm{mg} \mathrm{L}^{-1}$ erythromycin and $0.05 \mathrm{M} \mathrm{Na}_{2} \mathrm{SO}_{4}$ (ultrapure water) treated by the PEC process at $5 \mathrm{~mA} \mathrm{~cm}{ }^{-2}, 25^{\circ} \mathrm{C}, 2 \mathrm{~L} \mathrm{~min}^{-1} \mathrm{O}_{2}$, under the following pHs: $(\square) 2.8 ;(*) 5.0 ;(+) 7.0$. 
The optimal $\mathrm{pH}$ for the PEC process was 2.8 , the same as the most favourable $\mathrm{pH}$ found for Fenton process [42,43]. At $\mathrm{pH}$ values close to 2.8, the predominant ions of iron, ferrous and ferric, are dissolved in the form of aqua-complexes, highlighting as main compounds the $\left[\mathrm{Fe}^{\mathrm{II}}\left(\mathrm{H}_{2} \mathrm{O}\right)_{6}\right]^{2+},\left[\mathrm{Fe}^{\mathrm{III}}(\mathrm{OH})\left(\mathrm{H}_{2} \mathrm{O}\right)_{5}\right]^{2+},\left[\mathrm{Fe}^{\mathrm{III}}(\mathrm{OH})_{2}\left(\mathrm{H}_{2} \mathrm{O}\right)_{4}\right]^{+}$and $\left[\mathrm{Fe}^{\mathrm{III}}\left(\mathrm{H}_{2} \mathrm{O}\right)_{6}\right]^{3+}$ and, to lesser extent, $\left[\mathrm{Fe}_{2}\left(\mathrm{H}_{2} \mathrm{O}\right)_{8}(\mathrm{OH})_{2}\right]^{4+}[47,48]$. However, we determined that at $\mathrm{pH}$ 5.0 , around $0.2-0.6 \%$ iron was dissolved $\left(0.2-1.1 \mathrm{mg} \mathrm{L}^{-1}\right)$, whereas at $\mathrm{pH} 7.0$ all iron was precipitated. As observed by Serra-Clusellas et al. [49], minute concentrations of Fe(III) $\left(0.6 \mathrm{mg} \mathrm{L}^{-1}\right)$ were enough to promote the Fenton-like reaction and the mineralization of organic pollutants at $\mathrm{pH}$ 3.6. This fact was then confirmed in the current work at $\mathrm{pH}$ 5.0, where around $25 \%$ of DOC was removed after applying $0.32 \mathrm{~A} \mathrm{~h} \mathrm{~L}^{-1}$. Unlike $\mathrm{pH} 5.0$, no mineralization was reached at $\mathrm{pH}$ 7.0; on the contrary, an increase of DOC throughout the treatment was observed. This rise can be associated to organic leaches from silicone tubs used for the peristaltic pump for recirculating the solution, which can be partially oxidized by hydrogen peroxide and other reactive oxygen species. This fact evidenced that mineralization percentage obtained in this article could be higher if other tubbing materials were used.

Despite this, the most suitable operating conditions found in this work are as follows: PEC treatment at $5 \mathrm{~mA} \mathrm{~cm}^{-2}$, injecting $2.0 \mathrm{~L} \mathrm{~min}^{-1} \mathrm{O}_{2}$ at $\mathrm{pH} 2.8$.

\subsection{Identification of Aromatic Byproducts of Erythromycin and Degradation Pathway Proposed}

Aromatic byproducts generated during the early stage of the erythromycin mineralization pathway were identified for the PEC process at the most suitable operational conditions, specified above.

Most of transformation products for erythromycin and its degradation pathways have already discussed in bibliography [16,35-39] under different conditions but it has not been investigated under PEC water remediation process. Pérez et al. [31] identified the intermediates formed at 30 and $120 \mathrm{~min}$ of the solar photo electro-Fenton process of a $165 \mathrm{mg} \mathrm{L}^{-1}$ erythromycin solution at $\mathrm{pH} 3$ and $j_{\text {cathode }}=0.16 \mathrm{~mA} \mathrm{~cm}^{-2}$, determined by GCMS. However, no information was found about the first intermediates generated during the early stages of the erythromycin mineralization pathway by the electrochemical-Fenton based processes.

In this paper we used chromatographic separation behaviour and high-resolution tandem mass spectrometry HRMS ${ }^{2}$ for the identification and quantification of erythromycin transformation products. By using this approach, 23 erythromycin intermediates were putative identified by their theoretical exact mass, logical retention time (compared to bibliography) and diagnostic tandem mass ions. In addition, these compounds were quantified by using an erythromycin IS calibration curve and their concentration (erythromycin +23 intermediates) throughout the PEC treatment time are presented on Table 3.

Table 3. Erythromycin and aromatic intermediates detected during PEC of $10 \mathrm{mg} \mathrm{L}^{-1}$ erythromycin and $0.05 \mathrm{M} \mathrm{Na}_{2} \mathrm{SO}_{4}$ (ultrapure water) at $5 \mathrm{~mA} \mathrm{~cm}{ }^{-2}, 25^{\circ} \mathrm{C}, 2 \mathrm{~L} \mathrm{~min}^{-1} \mathrm{O}_{2}, \mathrm{pH}=2.8$.

\begin{tabular}{|c|c|c|c|c|c|c|c|c|c|c|}
\hline \multirow[b]{2}{*}{$\mathbf{N}^{\circ}$} & \multirow[b]{2}{*}{ Compound } & \multirow[b]{2}{*}{$\begin{array}{l}\text { Molecular } \\
\text { Formula }\end{array}$} & \multirow{2}{*}{$\begin{array}{l}\text { Pseudo- } \\
\text { Molecular } \\
\text { Ion }(m / z)\end{array}$} & \multirow{2}{*}{$\begin{array}{l}\text { Retention } \\
\text { Time } \\
\text { (min) }\end{array}$} & \multicolumn{6}{|c|}{ Compound Concentration ( $\mu \mathrm{g} \mathrm{L}^{-1}$ ) } \\
\hline & & & & & $\begin{array}{c}0 \text { min } \\
\text { pH } 2.8\end{array}$ & $5 \mathrm{~min}$ & $15 \mathrm{~min}$ & $30 \mathrm{~min}$ & $45 \mathrm{~min}$ & $\begin{array}{c}60 \\
\text { min }\end{array}$ \\
\hline 1 & Erythromycin (Erythromycin A) & $\mathrm{C}_{37} \mathrm{H}_{67} \mathrm{NO}_{13}$ & 734.4685 & 4.0 & 457.4 & 17.9 & 0.8 & $\begin{array}{c}\text { Non } \\
\text { detected } \\
\text { (n.d.) }\end{array}$ & n.d. & n.d. \\
\hline 2 & Erythromycin B & $\mathrm{C}_{37} \mathrm{H}_{67} \mathrm{NO}_{12}$ & 718.4736 & 4.6 & 204.1 & 47.0 & 0.5 & n.d. & n.d. & n.d. \\
\hline 3 & Erythromycin C & $\mathrm{C}_{36} \mathrm{H}_{65} \mathrm{NO}_{13}$ & 720.4529 & 3.5 & 5.2 & n.d. & n.d. & n.d. & n.d. & n.d. \\
\hline 4 & Erythromycin C anhydrous & $\mathrm{C}_{36} \mathrm{H}_{63} \mathrm{NO}_{12}$ & 702.4423 & 4.2 & 61.1 & 19.2 & 0.2 & n.d. & n.d. & n.d. \\
\hline 5 & $\begin{array}{l}\text { Erythromycin A desosamine } \\
\text { N-demethylation }\end{array}$ & $\mathrm{C}_{36} \mathrm{H}_{65} \mathrm{NO}_{13}$ & 720.4529 & 3.9 & 13.5 & 2.3 & 1.5 & n.d. & n.d. & n.d. \\
\hline 6 & Erythromycin E & $\mathrm{C}_{37} \mathrm{H}_{65} \mathrm{NO}_{14}$ & 748.4478 & 3.9 & 301.3 & 71.0 & 2.9 & n.d. & n.d. & n.d. \\
\hline
\end{tabular}


Table 3. Cont.

\begin{tabular}{|c|c|c|c|c|c|c|c|c|c|c|}
\hline \multirow[b]{2}{*}{$\mathbf{N}^{\circ}$} & \multirow[b]{2}{*}{ Compound } & \multirow[b]{2}{*}{$\begin{array}{l}\text { Molecular } \\
\text { Formula }\end{array}$} & \multirow{2}{*}{$\begin{array}{l}\text { Pseudo- } \\
\text { Molecular } \\
\text { Ion }(\mathrm{m} / \mathrm{z})\end{array}$} & \multirow{2}{*}{$\begin{array}{l}\text { Retention } \\
\text { Time } \\
\text { (min) }\end{array}$} & \multicolumn{6}{|c|}{ Compound Concentration $\left(\mu \mathrm{g} \mathrm{L}^{-1}\right)$} \\
\hline & & & & & $\begin{array}{l}0 \mathrm{~min} \\
\mathrm{pH} 2.8\end{array}$ & $5 \mathrm{~min}$ & $15 \mathrm{~min}$ & $30 \mathrm{~min}$ & $45 \mathrm{~min}$ & $\begin{array}{c}60 \\
\min \end{array}$ \\
\hline 7 & $\begin{array}{l}\text { Erythromycin E dehydration + } \\
\text { dehydroxylation }\end{array}$ & $\mathrm{C}_{37} \mathrm{H}_{63} \mathrm{NO}_{12}$ & 714.4423 & 5.2 & 22.1 & 99.3 & 1.2 & n.d. & n.d. & n.d. \\
\hline 8 & $\begin{array}{l}\text { Erythromycin E dehydration + } \\
\text { dehydroxylation—cladinose }\end{array}$ & $\mathrm{C}_{29} \mathrm{H}_{49} \mathrm{NO}_{9}$ & 556.348 & 4.3 & n.d. & 46.7 & 5.0 & n.d. & n.d. & n.d. \\
\hline 9 & Erythromycin F & $\mathrm{C}_{37} \mathrm{H}_{67} \mathrm{NO}_{14}$ & 750.4634 & 3.7 & 241.7 & 14.5 & n.d. & n.d. & n.d. & n.d. \\
\hline 10 & Erythromycin F-cladinose TP-1 & $\mathrm{C}_{29} \mathrm{H}_{53} \mathrm{NO}_{11}$ & 592.3691 & 2.5 & 99.1 & 43.6 & 2.3 & n.d. & n.d. & n.d. \\
\hline 11 & Erythromycin F-cladinose TP-2 & $\mathrm{C}_{29} \mathrm{H}_{53} \mathrm{NO}_{11}$ & 592.3691 & 2.6 & 1.2 & 64.3 & 3.2 & n.d. & n.d. & n.d. \\
\hline 12 & Erythromycin A-cladinose & $\mathrm{C}_{29} \mathrm{H}_{53} \mathrm{NO}_{10}$ & 576.3742 & 3.0 & 68.1 & 149.0 & 9.1 & n.d. & n.d. & n.d. \\
\hline 13 & $\begin{array}{l}\text { Erythromycin F enol ether or } \\
\text { anhydrous }\end{array}$ & $\mathrm{C}_{37} \mathrm{H}_{65} \mathrm{NO}_{13}$ & 732.4529 & 3.6 & 3.5 & 20.8 & 0.8 & n.d. & n.d. & n.d. \\
\hline 14 & $\begin{array}{l}\text { Erythromycin F } \\
\text { dehydrogenation TP-1 }\end{array}$ & $\mathrm{C}_{37} \mathrm{H}_{65} \mathrm{NO}_{14}$ & 748.4478 & 3.5 & 0.7 & 31.4 & 0.8 & n.d. & n.d. & n.d. \\
\hline 15 & $\begin{array}{l}\text { Erythromycin F } \\
\text { dehydrogenation TP-2 }\end{array}$ & $\mathrm{C}_{37} \mathrm{H}_{65} \mathrm{NO}_{14}$ & 748.4478 & 3.9 & 12.8 & 61.0 & 3.1 & n.d. & n.d. & n.d. \\
\hline 16 & $\begin{array}{l}\text { Erythromycin F enol ether or } \\
\text { anhydrous + lactone } \\
\text { dehydration TP-1 }\end{array}$ & $\mathrm{C}_{37} \mathrm{H}_{63} \mathrm{NO}_{12}$ & 714.4423 & 4.4 & 40.6 & 21.1 & 0.2 & n.d. & n.d. & n.d. \\
\hline 17 & $\begin{array}{l}\text { Erythromycin F enol ether or } \\
\text { anhydrous + lactone } \\
\text { dehydration TP-2 }\end{array}$ & $\mathrm{C}_{37} \mathrm{H}_{63} \mathrm{NO}_{12}$ & 714.4423 & 4.8 & 20.9 & 27.4 & 0.2 & n.d. & n.d. & n.d. \\
\hline 18 & $\begin{array}{l}\text { Erythromycin F enol ether or } \\
\text { anhydrous + lactone } \\
\text { dehydration-cladinose }\end{array}$ & $\mathrm{C}_{29} \mathrm{H}_{49} \mathrm{NO}_{9}$ & 556.348 & 3.0 & n.d. & 5.6 & 0.4 & n.d. & n.d. & n.d. \\
\hline 19 & Erythromycin A enol ether TP-1 & $\mathrm{C}_{37} \mathrm{H}_{65} \mathrm{NO}_{12}$ & 716.458 & 4.8 & 5.1 & 4.4 & n.d. & n.d. & n.d. & n.d. \\
\hline 20 & Erythromycin A enol ether TP-2 & $\mathrm{C}_{37} \mathrm{H}_{65} \mathrm{NO}_{12}$ & 716.458 & 5.2 & 1.8 & 8.6 & 0.1 & n.d. & n.d. & n.d. \\
\hline 21 & $\begin{array}{l}\text { Erythromycin A enol } \\
\text { ether-cladinose }\end{array}$ & $\mathrm{C}_{29} \mathrm{H}_{51} \mathrm{NO}_{9}$ & 558.3637 & 4.2 & 20.5 & 7.2 & n.d. & n.d. & n.d. & n.d. \\
\hline 22 & Erythromycin A anhydrous & $\mathrm{C}_{37} \mathrm{H}_{65} \mathrm{NO}_{12}$ & 716.458 & 4.5 & 1533.5 & 432.0 & 2.6 & n.d. & n.d. & n.d. \\
\hline 23 & $\begin{array}{l}\text { Erythromycin A anhydrous } \\
\text { desosamine N-demethylation }\end{array}$ & $\mathrm{C}_{36} \mathrm{H}_{63} \mathrm{NO}_{12}$ & 702.4423 & 4.4 & 56.2 & 3.5 & n.d. & n.d. & n.d. & n.d. \\
\hline 24 & $\begin{array}{l}\text { Erythromycin A } \\
\text { anhydrous-cladinose }\end{array}$ & $\mathrm{C}_{29} \mathrm{H}_{51} \mathrm{NO}_{9}$ & 558.3637 & 3.5 & 46.7 & 79.4 & 4.7 & n.d. & n.d. & n.d. \\
\hline
\end{tabular}

The erythromycin degradation pathway proposed for the early stage of the PEC process is represented in Figure 5.

As described in the literature, the decomposition of erythromycin A proceeds via the known intermediate erythromycin A-6,9-hemiketal. The monodehydroxylation or didehydroxylation of this intermediate produced the main compounds described in the literature, i.e., erythromycin A enol ether isomers $(716.458 \mathrm{~m} / \mathrm{z}$ ) (compounds 19 and 20 of Figure 5) and anhydrous erythromycin A $(716.458 \mathrm{~m} / \mathrm{z}$ ) (compound 22), respectively. Sequentially, the respective transformation products of the compounds 19, 20 and 22 from the cleavage of cladinose group were assigned (compounds 21 and 23) by their exact mass and the observation of unmodified desosamine fragment $(158.1176 \mathrm{~m} / \mathrm{z})$ and cladinose neutral loss $\left([\mathrm{M}+\mathrm{H}-158.0937]^{+} \mathrm{m} / z\right)$. These results indicated that the delta mass observed was produced on the lactone part of erythromycin A. The last two compounds were assigned on the basis of their similar fragmentation pattern in respect of their precursor compound (480-580 $\mathrm{m} / \mathrm{z}$ range), where neutral losses of water from lactone part are observed. Thus, anhydrous erythromycin A (compound 22) either with or without a cladinose moiety had two consecutive losses of water from $558.3637 \mathrm{~m} / \mathrm{z}$ ion, whereas erythromycin A enol ether (compound 19) either with or without cladinose moiety had only one losses of water from $558.3637 \mathrm{~m} / \mathrm{z}$ ion. In addition, an isomer of erythromycin A enol ether was identified (compound 20) since their fragmentation pattern was equal between the two chromatographic peaks. 

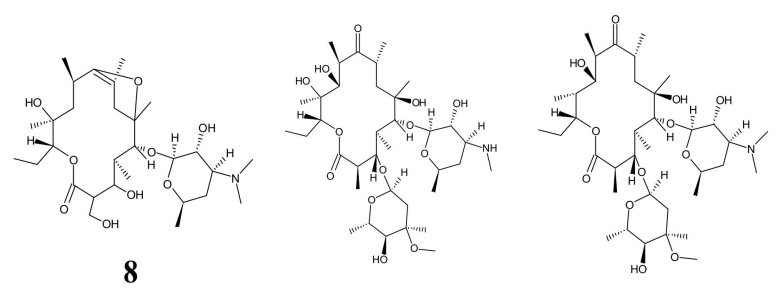

2
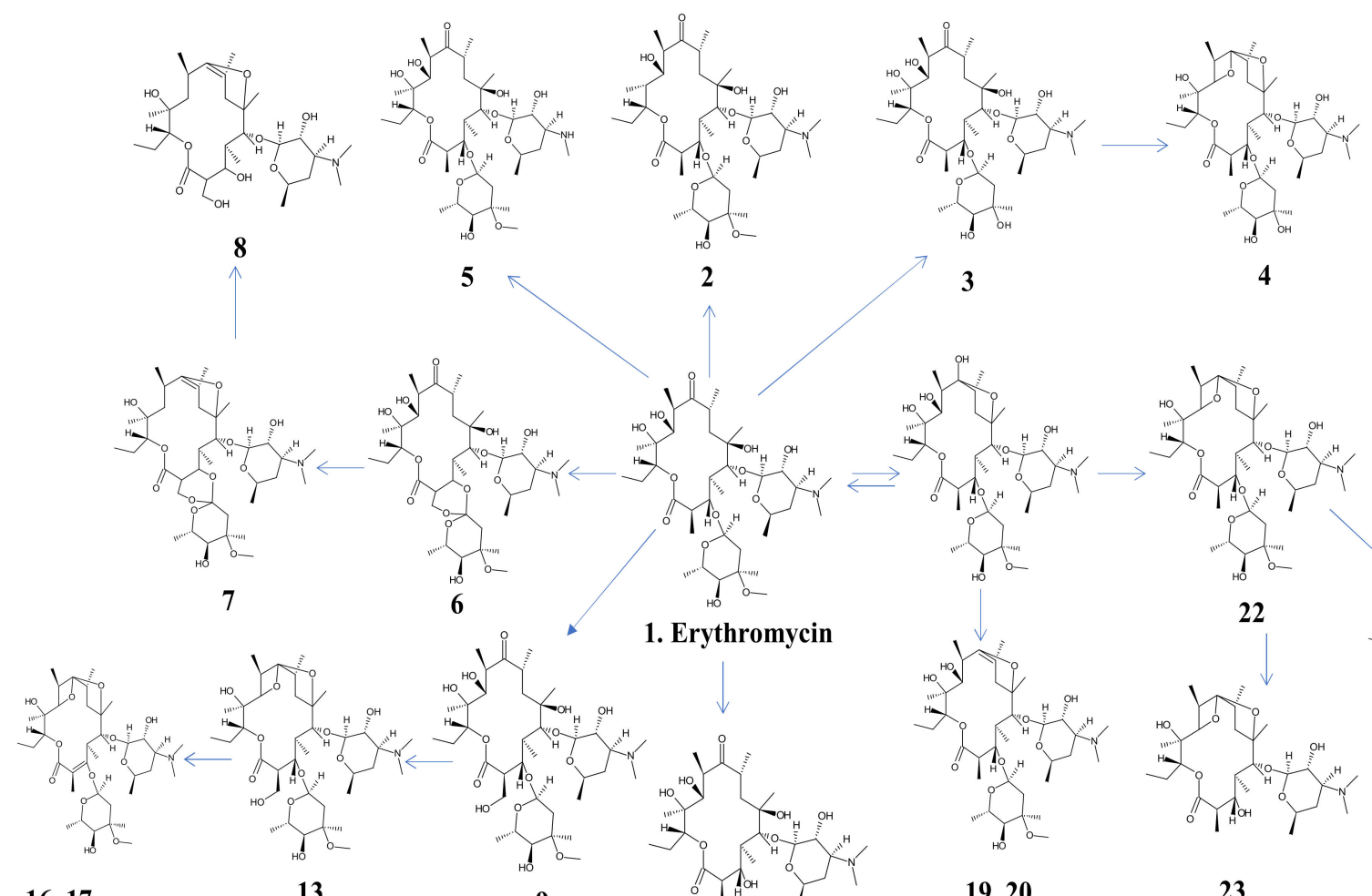

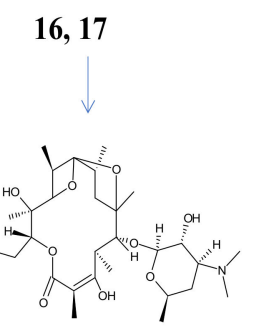

18

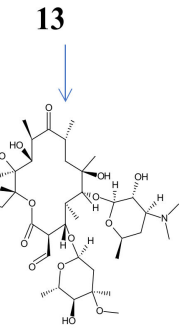

14,15

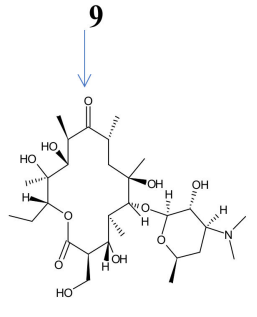

10,11

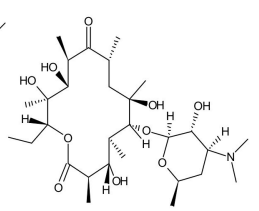

12

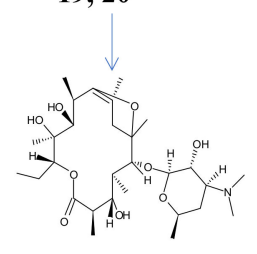

21

Figure 5. Proposed early-stage mineralization pathway for the removal of $10 \mathrm{mg} \mathrm{L}^{-1}$ erythromycin (ultrapure water) by the PEC process.

Moreover, erythromycin A without a cladinose sugar (compound 12) was identified based on the no observation of the neutral loos of cladinose and the observation of desosamine fragment, as well as other erythromycin isomers such as erythromycin B (compound 2), erythromycin C (compound 3), erythromycin E (compound 6) and erythromycin $\mathrm{F}$ (compound 9) and some of their transformation products concerning the cleavage of cladinose moiety (compound 8, 10,11). Erythromycin isomers A, C, E and F dehydrate produced the compounds 22, 4, 13 and 7, respectively. For example, tandem mass spectrum of erythromycin $\mathrm{C}$ and erythromycin $\mathrm{C}$ anhydrous had the neutral loss of the modified cladinose $\left(-\mathrm{OH}\right.$ instead of $\left.-\mathrm{OCH}_{3}\right)$. All this transformation products have already been described for different remediation processes and follow the proposed degradation pathway indicated in Figure 5. Nonetheless, we found other interesting signals $(732,714$, and $555 \mathrm{~m} / \mathrm{z}$ ) that had a delta mass of $-2 \mathrm{~m} / \mathrm{z}$ of the main erythromycin A transformation products explained before. Thus, their tandem mass spectra were also carefully inspected and we hypothesize that a degradation of erythromycin-A is promoted by the formation of erythromycin F $(750.4634 \mathrm{~m} / \mathrm{z})$ intermediate (compound 9) and its degradation to erythromycin F enol ether or anhydrous $(732.4529 \mathrm{~m} / \mathrm{z}$ ) (compound 13) and its lactone dehydration $(714.4423 \mathrm{~m} / \mathrm{z}$ ) (isomers 16 and 17) and successive cladinose cleavage (556.348 $m / z$ ) (compound 18), or compound 13 dehydrogenation $(748.4478 \mathrm{~m} / \mathrm{z}$ ) producing two isomers (compounds 14 and 15). Finally, an N-demethylation of erythromycin A generated the intermediate 5 . 
The results of the Table 3 show that none of these compounds were detected after 30 min of treatment, all of them thus being early-stage intermediates.

Another aspect to highlight is that after adjusting the $\mathrm{pH}$ to 2.8 , and before starting the PEC process ( $0 \mathrm{~min}$ ), only $5 \%$ of the initial erythromycin (erythromycin A, compound 1 ) remained in solution. $28 \%$ of this substance was degraded to the 23 intermediates detected in this work, being the erythromycin A anhydrous (compound 22) the most detected byproduct produced (approximately 15\%). This means that $67 \%$ of the initial erythromycin was degraded to other byproducts not determined in this article just due to the acidification. This acid-catalysed water molecule loss from erythromycin occurs rapidly at $\mathrm{pH}<4[50,51]$. Therefore, this is an important aspect to be considered in future works, especially when working or analysing the erythromycin in acid $\mathrm{pH}$ solutions.

\subsection{Extrapolation of the PEC Process to a Real Effluent}

Finally, the PEC process under the most appropriate conditions $\left(5 \mathrm{~mA} \mathrm{~cm}{ }^{-2}\right.$, injecting 2.0 $\mathrm{L} \mathrm{min}^{-1} \mathrm{O}_{2}$ into the cathode and $\mathrm{pH}$ 2.8) was validated by treating a real effluent obtained from the tertiary treatment (coagulation/flocculation and sand filtration) of an urban WWTP. Its composition is shown in Table 4.

Table 4. Composition of the effluent from the tertiary treatment of an urban WWTP.

\begin{tabular}{ccc}
\hline Parameter & Units & Value \\
\hline $\mathrm{pH}$ & - & 7.6 \\
\hline Electrical conductivity & $\mathrm{ms} \mathrm{cm}^{-1}$ & 1.5 \\
\hline Total Inorganic Carbon & $\mathrm{mg} \mathrm{L}^{-1}$ & 72.8 \\
\hline DOC & $\mathrm{mg} \mathrm{L}^{-1}$ & 9.9 \\
\hline Total N & $\mathrm{mg} \mathrm{L}^{-1}$ & 33.1 \\
\hline
\end{tabular}

No electrolyte was added to the water. The concentrations of the emerging compounds included in the Watch List 2018 in the influent and effluent of the electrochemical treatment are summarized in Table 5.

Table 5. Concentration of the compounds listed in the Watch List 2018 in the analysed effluents.

\begin{tabular}{|c|c|c|c|}
\hline Compound & $\begin{array}{l}\text { Effluent from the Tertiary } \\
\text { Treatment of an Urban } \\
\left.\text { WWTP (ng L }{ }^{-1}\right)\end{array}$ & $\begin{array}{l}\text { Treated Effluent from the } \\
\text { PEC Treatment (ng } L^{-1} \text { ) }\end{array}$ & Removals (\%) \\
\hline E1 & 858 & 5 & $99 \%$ \\
\hline E2 & 127 & $<\mathrm{MLOQ}$ & $>99 \%$ \\
\hline EE2 & 117 & 1 & $99 \%$ \\
\hline Amoxicillin trihydrate & $<\mathrm{MLOQ}$ & $<\mathrm{MLOQ}$ & - \\
\hline Thiamethoxam & 7 & $<\mathrm{MLOQ}$ & $>86 \%$ \\
\hline Ciprofloxacin & 1 & $<\mathrm{MLOQ}$ & - \\
\hline Clothianidin & 6 & $<\mathrm{MLOQ}$ & $>83 \%$ \\
\hline Imidacloprid & 60 & $<\mathrm{MLOQ}$ & $>83 \%$ \\
\hline Acetamiprid & 30 & $<$ MLOQ & $>97 \%$ \\
\hline Thiacloprid & 21 & $<\mathrm{MLOQ}$ & $>95 \%$ \\
\hline Azythromycin & 365 & $<\mathrm{MLOQ}$ & $100 \%$ \\
\hline Erythromycin & 23 & $<\mathrm{MLOQ}$ & $>74 \%$ \\
\hline Methiocarb & 30 & $<$ MLOQ & $>33 \%$ \\
\hline Clarythromycin & 31 & $<\mathrm{MLOQ}$ & $>97 \%$ \\
\hline Metaflumizone & 17 & $<$ MLOQ & $>65 \%$ \\
\hline
\end{tabular}


In general terms, the compounds found in the WWTP tertiary effluent (PEC influent) were not detected in the treated PEC effluent, except for E1 and EE2, although high degradation percentages were achieved ( $99 \%$ removal). As commented before, the determination of erythromycin, but also the amoxicillin, is significantly affected by the low $\mathrm{pH}$ in the treated water, since the internal standard is not stable in the acidic conditions. The initial DOC of the water was $9.9 \mathrm{mg} \mathrm{L}^{-1}$ and its evolution was plotted in Figure 6.

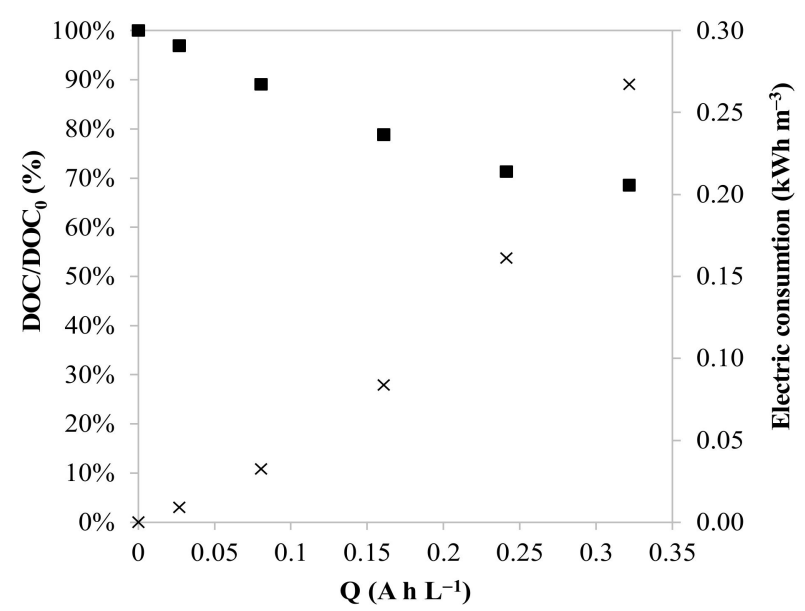

Figure 6. Evolution of the DOC $(\boldsymbol{\square})$ and the electric consumption (x) through the applied charge in $1 \mathrm{~L}$ of an effluent from an urban WWTP treated by the PEC process at $5 \mathrm{~mA} \mathrm{~cm}^{-2}, 25^{\circ} \mathrm{C}, 2 \mathrm{~L} \mathrm{~min}^{-1}$ $\mathrm{O}_{2}$ at $\mathrm{pH} 2.8$.

Approximately 30\% DOC was removed at the end of the PEC treatment, applying $0.32 \mathrm{~A} \mathrm{~h} \mathrm{~L}^{-1}$. The electricity consumption associated to the electrochemical cell was around $0.4 \mathrm{kWh} \mathrm{m}^{-3}$, that means a cost of around $0.09 € \mathrm{~m}^{-3}$, considering the Spanish electricity price in first half 2020 was $0.2239 € \mathrm{kWh}^{-1}$ [52]. This low electricity consumption with the high degradation efficiencies for all the compounds of the Watch List 2018, appoint the PEC as a potential technology to be applied for removing these types of emerging compounds from waters, preventing their arrival to the aquatic systems, and thus improving the water quality of the environment. Future studies should also include toxicity assays of the transformation byproducts generated during the PEC treatment to ensure a suitable final quality of water.

These results indeed suggested PEC as a promising technology to be implemented for water and wastewater remediation. For example, PEC can be applied to treat complex industrial wastewaters such as pharmaceutical or leachate effluents coupled before a biological treatment to increase water biodegradability. However, a neutralization step must be applied after the PEC process to send the effluent to a biological treatment. Also, this post-treatment would be required if the effluent was discharged to a municipal sewer in order to reduce the iron concentration below the limit sets by the legislation $\left(10 \mathrm{mg} \mathrm{L}^{-1}\right.$ $\mathrm{Fe}$, in the case of Catalunya [44]).

\section{Conclusions}

The results of this investigation demonstrate the technical and economic feasibility of the peroxyelectrocoagulation (PEC) process to degrade contaminants of emerging concern present in water such as those included in the EU Decision 2018/840 (Watch List 2018). The article proves that PEC can degrade most of the compounds included in the Watch List 2018 below their quantification limit and mineralize the $25 \%$ DOC of a real WWTP tertiary effluent, applying an electrical charge of $0.32 \mathrm{~A} \mathrm{~h} \mathrm{~L}^{-1}$, a current density $j_{\text {anode }}=$ $5 \mathrm{~mA} \mathrm{~cm}^{-2}$, injecting $2.0 \mathrm{~L} \mathrm{~min}^{-1} \mathrm{O}_{2}$ into the cathode and keeping the $\mathrm{pH}$ at 2.8. The electricity consumption of the cell was $0.27 \mathrm{kWh} \mathrm{m}^{-3}$. These operational conditions were selected by previously studying the removal erythromycin from ultrapure water, obtaining $70 \%$ mineralization with an electricity consumption of $1.7 \mathrm{kWh} \mathrm{m}^{-3}$. The research also 
revealed the early-stage transformation byproducts generated during the erythromycin mineralization, by identifying and quantifying 23 erythromycin intermediates.

Author Contributions: EF and PEC experiments: A.S.-C., L.S., M.d.L.C.; erythromycin byproducts determination: P.H., A.D.-R.; determination of the emerging compounds of the Watch List 2018: M.R.; project proposal: A.S.-C. and A.C.; project management: A.S.-C., A.C., N.C., X.M.-L. All authors have read and agreed to the published version of the manuscript.

Funding: This work was financially supported by the Catalan Government through the funding grant ACCIÓ-Eurecat (Project PRIV2019-AVANÇ- $\mathrm{H}_{2} \mathrm{O}$ ).

Institutional Review Board Statement: Not applicable.

Informed Consent Statement: Not applicable

Data Availability Statement: Data sharing not applicable. No new data were created or analyzed in this study. Data sharing is not applicable to this article.

Acknowledgments: The authors would like to acknowledge the Sustainability Laboratory of EURECAT_Manresa facilities for the analysis of DOC and iron of the generated samples.

Conflicts of Interest: The authors declare no conflict of interest.

\section{References}

1. Carlsson, C.; Johansson, A.K.; Alvan, G.; Bergman, K.; Kühler, T. Are pharmaceuticals potent environmental pollutants? Part I: Environmental risk assessments of selected active pharmaceutical ingredients. Sci. Total Environ. 2006, 364, 67-87. [CrossRef]

2. Sousa, J.C.G.; Ribeiro, A.R.; Barbosa, M.O.; Ribeiro, C.; Tiritan, M.E.; Pereira, M.F.R.; Silva, A.M.T. Monitoring of the 17 EU Watch List contaminants of emerging concern in the Ave and the Sousa Rivers. Sci. Total Environ. 2019, 649, 1083-1095. [CrossRef]

3. Cunningham, V.L.; Binks, S.P.; Olson, M.J. Human health risk assessment from the presence of human pharmaceuticals in the aquatic environment. Regul. Toxicol. Pharmacol. 2009, 53, 39-45. [CrossRef]

4. European Commission. Commission Implementing Decision (EU) 2015/495 of 20 March 2015 Establishing a Watch List of Substances for Union-Wide Monitoring in the Field of Water Policy Pursuant to Directive 2008/105/EC of the European Parliament and of the Council; Office for Official Publications of the European Communities: Luxembourg, 2015. Available online: https://eur-lex.europa.eu/ legal-content/EN/TXT/PDF/?uri=CELEX:32015D0495\&from=EN (accessed on 18 April 2021).

5. European Commission. Commission Implementing Decision (EU) 2018/840 of 5 June 2018 Establishing a Watch List of Substances for Union-Wide Monitoring in the Field of Water Policy Pursuant to Directive 2008/105/EC of the European Parliament and of the Council and Repealing Commission Implementing Decision (EU) 2015/495; Office for Official Publications of the European Communities: Luxembourg, 2018. Available online: https://eur-lex.europa.eu/legal-content/EN/TXT/PDF/?uri=CELEX:32018D0840\&from= EN (accessed on 18 April 2021).

6. European Commission. Commission Implementing Decision (EU) 2020/1161 of 4 August 2020 Establishing a Watch List of Substances for Union-Wide Monitoring in the Field of Water Policy Pursuant to Directive 2008/105/EC of the European Parliament and of the Council; Office for Official Publications of the European Communities: Luxembourg, 2020. Available online: https://eur-lex.europa.eu/ legal-content/EN/TXT/PDF/?uri=CELEX:32020D1161\&from=EN (accessed on 18 April 2021).

7. Rodriguez-Mozaz, S.; Vaz-Moreira, I.; Varela Della Giustina, S.; Llorca, M.; Barceló, D.; Schubert, S.; Berendonk, T.U.; MichaelKordatou, I.; Fatta-Kassinos, D.; Martinez, J.L.; et al. Antibiotic residues in final effluents of European wastewater treatment plants and their impact on the aquatic environment. Environ. Int. 2020, 140, 105733. [CrossRef]

8. Polianciuc, S.I.; Gurzău, A.E.; Kiss, B.; Georgia Ștefan, M.; Loghin, F. Antibiotics in the environment: Causes and consequences. Med. Pharm. Rep. 2020, 93, 231-240. [CrossRef]

9. Hanna, N.; Sun, P.; Sun, Q.; Li, X.; Yang, X.; Ji, X.; Zou, H.; Ottoson, J.; Nilsson, L.E.; Berglund, B.; et al. Presence of antibiotic residues in various environmental compartments of Shandong province in eastern China: Its potential for resistance development and ecological and human risk. Environ. Int. 2018, 114, 131-142. [CrossRef] [PubMed]

10. World Health Organization. Antibiotic Resistance. 21 July 2020. Available online: https://www.who.int/news-room/factsheets/detail/antibiotic-resistance (accessed on 18 April 2021).

11. Veseli, A.; Mullallari, F.; Balidemaj, F.; Berisha, L.; Švorc, L.; Arbneshi, T. Electrochemical determination of erythromycin in drinking water resources by surface modified screen-printed carbon electrodes. Microchem. J. 2019, 148, 412-418. [CrossRef]

12. Carraro, E.; Bonetta, S.; Bertino, C.; Lorenzi, E.; Bonetta, S.; Gilli, G. Hospital effluents management: Chemical, physical, microbiological risks and legislation in different countries. J. Environ. Manag. 2016, 168, 185-199. [CrossRef] [PubMed]

13. Kovalova, L.; Siegrist, H.; von Gunten, U.; Eugster, J.; Hagenbuch, M.; Wittmer, A.; Moser, R.; McArdell, C.S. Elimination of micropollutants during post-treatment of hospital wastewater with powdered activated carbon, ozone, and UV. Environ. Sci. Technol. 2013, 47, 7899-7908. [CrossRef] [PubMed]

14. Ohlsen, K.; Ternes, T.; Werner, G.; Wallner, U.; Löffler, D.; Ziebuhr, W.; Witte, W.; Hacker, J. Impact of antibiotics on conjugational resistance gene transfer in Staphylococcus aureus in sewage. Environ. Microbiol. 2003, 5, 711-716. [CrossRef] 
15. Rueda-Márquez, J.J.; Palacios-Villarreal, C.; Manzano, M.; Blanco, E.; Ramírez del Solar, M.; Levchuk, I. Photocatalytic degradation of pharmaceutically active compounds (PhACs) in urban wastewater treatment plants effluents under controlled and natural solar irradiation using immobilized $\mathrm{TiO}_{2}$. Sol. Energy 2020, 208, 480-492. [CrossRef]

16. Llorca, M.; Rodríguez-Mozaz, S.; Couillerot, O.; Panigoni, K.; de Gunzburg, J.; Bayer, B.; Czaja, R.; Barceló, D. Identification of new transformation products during enzymatic treatment of tetracycline and erythromycin antibiotics at laboratory scale by an on-line turbulent flow liquid-chromatography coupled to a high resolution mass spectrometer LTQ-Orbitrap. Chemosphere 2015, 119, 90-98. [CrossRef] [PubMed]

17. Moslah, B.; Hapeshi, E.; Jrad, A.; Fatta-Kassinos, D.; Hedhili., A. Simultaneous Decontamination of Seven Residual Antibiotics in Secondary Treated Effluents by Solar Photo-Fenton and Solar $\mathrm{TiO}_{2}$ Catalytic Processes. In Recent Advances in Environmental Science from the Euro-Mediterranean and Surrounding Regions. EMCEI 2017. Advances in Science, Technology E Innovation (IEREK Interdisciplinary Series for Sustainable Development); Kallel, A., Ksibi, M., Ben Dhia, H., Khélifi, N., Eds.; Springer: Cham, Switzerland, 2017. [CrossRef]

18. Klavarioti, M.; Mantzavinos, D.; Kassinos, D. Removal of residual pharmaceuticals from aqueous systems by advanced oxidation processes. Environ. Int. 2009, 35, 402-417. [CrossRef] [PubMed]

19. Brillas, E.; Martínez-Huitle, C.A. Decontamination of wastewaters containing synthetic organic dyes by electrochemical methods. An updated review. Appl. Catal. B Environ. 2015, 166-167, 603-643. [CrossRef]

20. Lima, V.B.; Goulart, L.A.; Rocha, R.S.; Steter, J.R.; Lanza, M.R.V. Degradation of antibiotic ciprofloxacin by different AOP systems using electrochemically generated hydrogen peroxide. Chemosphere 2020, 247, 125807. [CrossRef]

21. Liu, X.; Zhou, Y.; Zhang, J.; Luo, L.; Yang, Y.; Huang, H.; Peng, H.; Tang, L.; Mu, Y. Insight into electro-Fenton and photo-Fenton for the degradation of antibiotics: Mechanism study and research gaps. Chem. Eng. J. 2018, 347, 379-397. [CrossRef]

22. Fenton, H.J.H. Oxidation of tartaric acid in the presence of iron. J. Chem. Soc. 1894, 65, 899-910. [CrossRef]

23. Peres Ribeiro, J.; Nunes, M.I. Recent trends and developments in Fenton processes for industrial wastewater treatment-A critical review. Environ. Res. 2021, 197, 110957. [CrossRef] [PubMed]

24. Sychev, A.Y.; Isak, V.G. Iron compounds and the mechanisms of the homogeneous catalysis of the activation of $\mathrm{O}_{2}$ and $\mathrm{H}_{2} \mathrm{O}_{2}$ and of the oxidation of organic substrates. Russ. Chem. Rev. 1995, 64, 1105-1129. [CrossRef]

25. Vasudevan, S. An efficient removal of phenol from water by peroxi-electrocoagulation processes. J. Water Process Eng. 2014, 2, 53-57. [CrossRef]

26. Sandhwar, V.K.; Prasad, B. Comparison of electrocoagulation, peroxi-electrocoagulation and peroxi-coagulation processes for treatment of simulated purified terephthalic acid wastewater: Optimization, sludge and kinetic analysis. Korean J. Chem. Eng. 2018, 35, 909-921. [CrossRef]

27. Farhadi, S.; Aminzadeh, B.; Torabian, A.; Khatibikamal, V.; Alizadeh Fard, M. Comparison of COD removal from pharmaceutical wastewater by electrocoagulation, photoelectrocoagulation, peroxi-electrocoagulation and peroxi-photoelectrocoagulation processes. J. Hazard. Mater. 2012, 219-220, 35-42. [CrossRef] [PubMed]

28. Marselli, B.; Garcia-Gomez, J.; Michaud, P.-A.; Rodrigo, M.A.; Comninellis, C. Electrogeneration of hydroxyl radical on borondoped diamond electrodes. J. Environ. Sci. 2003, 150, D79-D83. [CrossRef]

29. Oturan, N.; Oturan, M.A. Chapter 8-Electro-Fenton Process: Background, New Developments, and Applications. In Electrochemical Water and Wastewater Treatment; Martínez-Huitle, C.A., Rodrigo, M.A., Scialdone, O., Eds.; Butterworth-Heinemann: Oxford, UK, 2018; pp. 193-221. ISBN 9780128131602. [CrossRef]

30. Li, S.; Liu, Y.; Ge, R.; Yang, S.; Zhai, Y.; Hua, T.; Ondon, B.S.; Zhou, Q.; Li, F. Microbial electro-Fenton: A promising system for antibiotics resistance genes degradation and energy generation. Sci. Total Environ. 2020, 699, 134160. [CrossRef] [PubMed]

31. Pérez, T.; Sirés, I.; Brillas, E.; Nava, J.L. Solar photoelectro-Fenton flow plant modeling for the degradation of the antibiotic erythromycin in sulfate medium. Electrochim. Acta 2017, 228, 45-56. [CrossRef]

32. Sánchez Ruíz, C. Fenton Reactions (FS-TER-003). Inditex. 2015. Available online: https:/ / www.wateractionplan.com/documents / 177327/558166/Fenton+reactions.pdf/087c01a6-7f9c-2f33-95e7-b8a5945b9162 (accessed on 12 April 2021).

33. APHA. Method 3500-Fe B. ASTMD 1068-77, Iron in Water, Test Method. In Standard Methods Standard Methods for the Examination of Water and Wastewater, 22nd ed.; American Public Health Association: Washington, DC, USA, 2012.

34. Welcher, F.J. Standard Methods of Chemical Analysis, 6th ed.; Huntington 2B; R.E. Krieger Publishing Company: Florida, FL, USA, 1975; pp. 1827-1828.

35. Hassanzadeh, A.; Barber, J.; Morris, G.A.; Gorry, P.A. Mechanism for the degradation of erythromycin A and erythromycin A 2'-Ethyl succinate in acidic aqueous solution. J. Phys. Chem. A 2007, 111, 10098-10104. [CrossRef]

36. Volmer, D.A.; Hui, J.P. Study of erythromycin A decomposition products in aqueous solution by solid-phase microextraction/liquid chromatography/tandem mass spectrometry. Rapid Commun. Mass Spectrom. 1998, 12, 123-129. [CrossRef]

37. Chitneni, S.K.; Govaerts, C.; Adams, E.; Van Schepdael, A.; Hoogmartens, J. Identification of impurities in erythromycin by liquid chromatography-mass spectrometric detection. J. Chromatogr. A 2004, 1056, 111-120. [CrossRef]

38. Deubel, A.; Fandino, A.S.; Sörgel, F.; Holzgrabe, U. Determination of erythromycin and related substances in commercial samples using liquid chromatography/ion trap mass spectrometry. J. Chromatogr. A 2006, 1136, 39-47. [CrossRef]

39. Luiz, D.B.; Genena, A.K.; Virmond, E.; José, H.J.; Moreira, R.F.; Gebhardt, W.; Schröder, H.F. Identification of degradation products of erythromycin A arising from ozone and advanced oxidation process treatment. Water Environ. Res. 2010, 82, 797-805. [CrossRef] 
40. Malvar, J.L.; Abril, C.; Martín, J.; Santos, J.L.; Aparicio, I.; Escot, C.; Basanta, A.; Alonso, E. Development of an analytical method for the simultaneous determination of the $17 \mathrm{EU}$ Watch List compounds in surface waters: A Spanish case study. Environ. Chem. 2018, 15, 493-505. [CrossRef]

41. Ganzenko, O.; Trellu, C.; Oturan, N.; Huguenot, D.; Péchaud, Y.; van Hullebusch, E.D.; Oturan, M.A. Electro-Fenton treatment of a complex pharmaceutical mixture: Mineralization efficiency and biodegradability enhancement. Chemosphere 2020, 253, 126659. [CrossRef] [PubMed]

42. Pignatello, J.J.; Liu, D.; Huston, P. Evidence for an additional oxidant in the photoassisted Fenton reaction. Environ. Sci. Technol. 1999, 33, 1832-1839. [CrossRef]

43. Wu, K.; Xie, Y.; Zhao, J.; Hidaka, H. Photo-Fenton degradation of a dye under visible light irradiation. J. Mol. Catal. A Chem. 1999, 144, 77-84. [CrossRef]

44. Diari Oficial de la Generalitat de Catalunya. DECRET 130/2003, de 13 de maig, pel qual s'aprova el Reglament dels serveis públics de sanejament. Diari Oficial de la Generalitat de Catalunya 2003, 3894, 11143-11158.

45. Buxton, G.V.; Greenstock, C.L.; Helman, W.P.; Ross, A.B. Critical-Review of Rate Constants for Reactions of Hydrated Electrons, Hydrogen-Atoms and Hydroxyl Radicals $\left({ }^{\bullet} \mathrm{OH} /{ }^{\bullet} \mathrm{O}^{-}\right)$in Aqueous-Solution. J. Phys. Chem. Ref. Data 1988, 17, 513-886. [CrossRef]

46. Grundl, T.; Delwiche, J. Kinetics of ferric oxyhydroxide precipitation. J. Contam. Hydrol. 1993, 4, 71-87. [CrossRef]

47. Faust, B.C.; Hoigné, J. Photolysis of Fe(III)-hydroxy complexes as source of OH radical in clouds, fog and rain. Atmos. Environ. 1990, 24, 79-89. [CrossRef]

48. Gallard, H.; De Laat, J.; Legube, B. Spectrophotometric study of the formation of iron(III)-hydroperoxy complexes in homogeneous aqueous solutions. Water Res. 1999, 33, 2929-2936. [CrossRef]

49. Serra-Clusellas, A.; De Angelis, L.; Lin, C.-H.; Vo, P.; Bayati, M.; Sumner, L.; Lei, Z.; Amaral, N.B.; Bertini, L.M.; Mazza, J.; et al. Abatement of 2,4-D by H2O2 solar photolysis and solar photo-Fenton-like process with minute Fe(III) concentrations. Water Res. 2018, 144, 572-580. [CrossRef]

50. Hirsch, R.; Ternes, T.; Haberer, K.; Kratz, K.-L. Occurrence of antibiotics in the aquatic environment. Sci. Total Environ. 1999, 225, 109-118. [CrossRef]

51. Zhang, Y.; Duan, L.; Wang, B.; Liu, C.S.; Jia, Y.; Zhai, N.; Blaney, L.; Yu, G. Efficient multiresidue determination method for 168 pharmaceuticals and metabolites: Optimization and application to raw wastewater, wastewater effluent, and surface water in Beijing, China. Environ. Pollut. 2020, 261, 114113. [CrossRef] [PubMed]

52. Eurostat. Electricity Prices (Including Taxes) for Household Consumers, First Half 2020. Available online: https:/ / ec.europa.eu/ eurostat/statistics-explained/index.php/Electricity_price_statistics (accessed on 5 March 2021). 